\title{
Synthesis and Biological Evaluation of Benzo[f]indole-4,9-diones $N$-Linked to Carbohydrate Chains as New Type of Antitumor Agents
}

\author{
Flaviana R. F. Dias, ${ }^{\#, a}$ Fabiana S. Guerra, ${ }^{\#, b}$ Fernanda A. Lima,, \\ Yasmin K. C. de Castro, ${ }^{\#, a}$ Vitor F. Ferreira, ${ }^{d}$ Vinícius R. Campos, ${ }^{a}$ \\ Patrícia D. Fernandes ${ }^{\circledR} *, s, b$ and Anna C. Cunha ${ }^{\oplus *, s, a}$ \\ ${ }^{a}$ Departamento de Química Orgânica, Instituto de Química, Universidade Federal Fluminense, \\ Campus do Valonguinho, 24020-141 Niterói-RJ, Brazil \\ ${ }^{b}$ Laboratório de Farmacologia da Dor e da Inflamação, Instituto de Ciências Biomédicas, \\ Universidade Federal do Rio de Janeiro, Cidade Universitária, 21941-902 Rio de Janeiro-RJ, Brazil \\ 'Departamento de Química Orgânica, Instituto de Química, \\ Universidade Federal do Rio de Janeiro, Centro de Tecnologia, Cidade Universitária, \\ 21941-909 Rio de Janeiro-RJ, Brazil \\ ${ }^{d}$ Departamento de Tecnologia Farmacêutica, Faculdade de Farmácia, \\ Universidade Federal Fluminense, Santa Rosa, 24241-002 Niterói-RJ, Brazil
}

\begin{abstract}
In this work, we report the synthesis of three series of carbohydrate-based benzo[f]indole4,9-diones and amino-1,4-naphthoquinone derivatives and evaluated their cytotoxic activity against eight human cancer cell lines. Several compounds showed a promising cytotoxic activity toward the tumor cell lines (half maximal inhibitory concentration $\left(\mathrm{IC}_{50}\right)<10.0 \mu \mathrm{M}$ ). The importance of the substitution pattern of the quinone derivatives on the antitumor activity was also discussed. 3-Carboethoxy-2-methyl-benzo[f]indole-4,9-dione derivatives were more cytotoxic than their parent compounds and amino-1,4-naphthoquinones. Unlike clinically useful anticancer agent doxorubicin, the majority of synthesized compounds did not exhibit any lytic effects against erythrocytes or normal human leukocytes.
\end{abstract}

Keywords: quinone, naphthoquinone, benzo[f]indole-4,9-dione, carbohydrate, antitumor activity

\section{Introduction}

The quinone ring is a common structural motif found in many antitumor compounds. ${ }^{1-4}$ For example, doxorubicin (1, Figure 1) is an anthracycline glycoconjugated antibiotic that exhibits biological activity against a wide variety of solid tumors in human patients. ${ }^{5,6}$ The daunosamine carbohydrate attached to the quinone ring plays an important role in the formation of a ternary deoxyribonucleic acid (DNA)-topoisomerase-anthraquinone complex that results in the inhibition of DNA replication and subsequent induction of apoptosis. ${ }^{7,8}$

*e-mail: patricia.dias.icbufrj@gmail.com; annac@vm.uff.br

\#These authors equally contributed on performing the experiments described in this article.

${ }^{\S}$ These authors equally contributed to this work and are co-senior authors.
Quinone compounds can exert their toxic effects through two important mechanisms: (i) as prooxidant agents, reducing oxygen to reactive oxygen species (ROS), including superoxide, hydrogen peroxide and hydroxyl radicals, by redox cycling, which cause damage to proteins, nucleic acids, lipids, membranes and organelles; and (ii) as alkylating agents, forming covalent DNA adducts that lead to DNA fragmentation. ${ }^{9-13}$

In addition to their ability to recognize a biological target, carbohydrates can improve the water-solubility of natural and synthetic compounds and decrease their toxicity side effects. ${ }^{14}$ Other relevant fact in sugarconjugates area is related to high carbohydrate consumption by cancerous tissues compared to normal tissues due to the high rate of aerobic glycolysis, increasing the selectivity index of glycoconjugated compounds against cancer cells. ${ }^{15}$ 

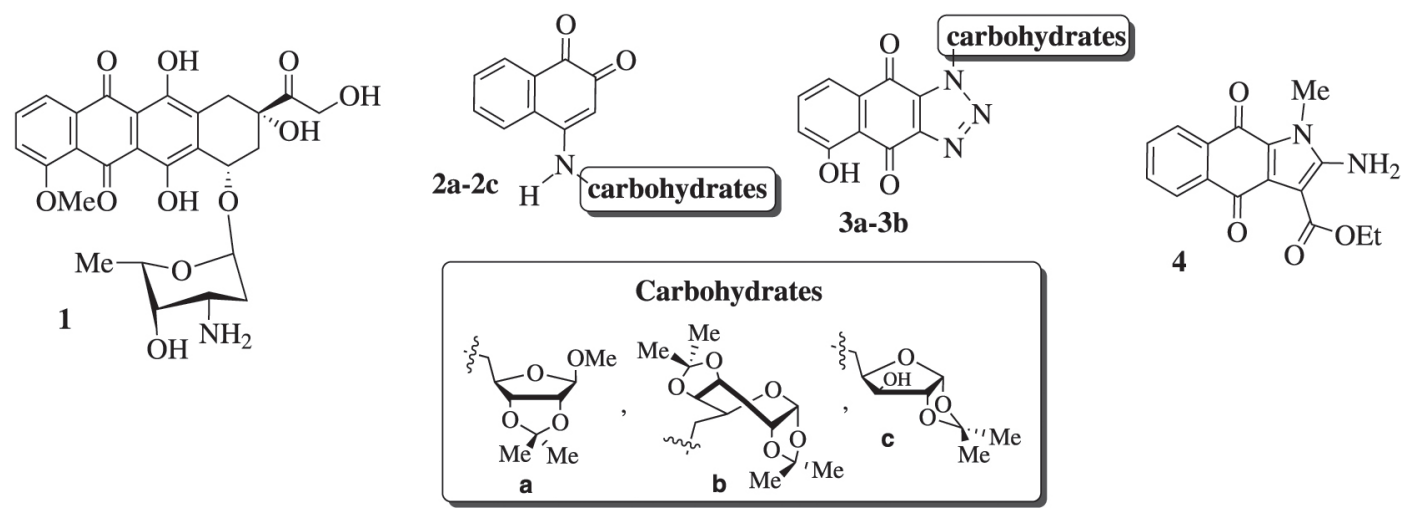

Figure 1. Some examples of natural $\mathbf{1}$ and synthetic 2-4 antitumor quinones.

With this goal in mind, we described the synthesis and pharmacological evaluation of carbohydrate-based 1,2-quinones 2a-2c and naphthotriazole derivatives 3a-3b (Figure 1). ${ }^{16,17}$ From this study, we identified five glycoconjugated compounds $\mathbf{2 a - 2 c}$ and $\mathbf{3 a - 3} \mathbf{3}$ with promising cytotoxic profiles against different human cancer cells, with the half maximal inhibitory concentration $\left(\mathrm{IC}_{50}\right)$ values ranging from $0.29-1.22$ and $0.64-3.66 \mu \mathrm{M}$, respectively.

Annulation of quinone with a series of functionalized pyrroles has been investigated by different research groups. The literature survey ${ }^{18,19}$ reveals that naphthoquinoneannelated pyrrole (4) (Figure 1) is a promising molecule for the synthetic design of new antitumor compounds. This derivative exhibit high cytotoxic activity against several cancer cell lines with $\mathrm{IC}_{50}$ values ranging from 0.3 to $1.5 \mu \mathrm{M}$, being comparable to the positive controls ellipticine and doxorubicin. Quinone 4 induced G2/M cell cycle arrest has been described as leading to apoptosis. ${ }^{20-22}$

Numerous synthetic methods have been developed to prepare benzo[f]indole-4,9-dione derivatives (Figure 2) that include: oxidative free radical reaction between 2-amino-1,4-naphthoquinones and active methylene compounds, or carbonyl compound or ethyl nitroacetate mediated by transition metals (Figure 2a);23-28 reaction of halo-quinones containing a carbonyl group with amines (Figure 2b); ${ }^{21-29}$ ceric ammonium nitrate (CAN)-catalyzed three-component reaction between primary amines, $\beta$-dicarbonyl compounds and 2-bromonaphthoquinones (Figure 2c); ${ }^{30} \mathrm{C}, N$-dialkylation of $\beta$-enaminones by 2,3-dichloronaphthoquinone (Figure $2 \mathrm{~d}$ ) $;{ }^{31}$ oxidative copper(II)-mediated reaction between enaminones and 1,4-naphthoquinone (Figure 2e); $;^{32,33}$ palladiumcatalyzed cross-coupling of 3-amino-substituted2-bromo-1,4-naphthoquinones with terminal acetylene derivatives (Figure 2f); ${ }^{34}$ silver-catalyzed tandem reaction of tosylmethylisocyanide (TosMIC) with 2-methyleneindene-1,3-diones (Figure 2g); ${ }^{35}$ Diels-Alder reaction of indole-4,7-dione with functionalized dienes (Figure $2 \mathrm{~h}$ ); ${ }^{36} \mathrm{Mn}^{\mathrm{II}}$-catalyzed reaction between vinyl azides and 2-hydroxynaphthoquinone (Figure 2i) $;{ }^{37}$ onepot multicomponent domino reaction (MDR) between 2-amino-1,4-naphthoquinone, $N$-acylmethylpyridinium bromides and aromatic aldehydes (Figure $2 \mathrm{j})^{22}$ and reaction of substituted $\alpha$-bromonitroalkenes with various $N$-arylated aminonaphthoquinones (Figure 2k). ${ }^{38}$

Here, our research focus is to develop a new class of benzo[f]indole-4,9-dione derivatives 5a-5c (Figure 3) $N$-linked to carbohydrate chains via reaction between halogenated naphthoquinone containing an $\alpha$-methylene carbonyl functional group and amino-carbohydrates to act more selectively against tumor cells in vitro than the prototype compound $\mathbf{4}$. The choice of sugars containing cyclic acetal group was based on our previous works, ${ }^{16,17}$ which have shown to add important structural features for the biological activity. It is important to note that there is a drug on the pharmaceutical market that contains two units of acetonides in its structure. ${ }^{39}$ To investigate the effect of substitution pattern around the pyrrole core on antitumor activity, we have prepared the related compounds $\mathbf{6 a - 6 c}$ and $\mathbf{7 a - 7 c}$ by cerium(IV)-mediated oxidative free radical cyclization reaction of 2-amino-1,4-naphthoquinone glycoconjugates 8a-8c with $\beta$-dicarbonyl compounds.

\section{Results and Discussion}

\section{Chemistry}

Aminocarbohydrates 9a-9c have been synthesized from their corresponding commercially reagents D-ribose (10a), D-galactose (10b) and D-xylose (10c) by using known methods (Scheme 1) of acetonization of hydrophilic groups, tosylation of partially protected carbohydrate derivatives, $\mathrm{S}_{\mathrm{N}} 2$ (bimolecular nucleophilic substitution) of functionalizedsugars with sodium azide and catalytic hydrogenation of organic azides to amines using palladium catalyst. ${ }^{9,40}$ 


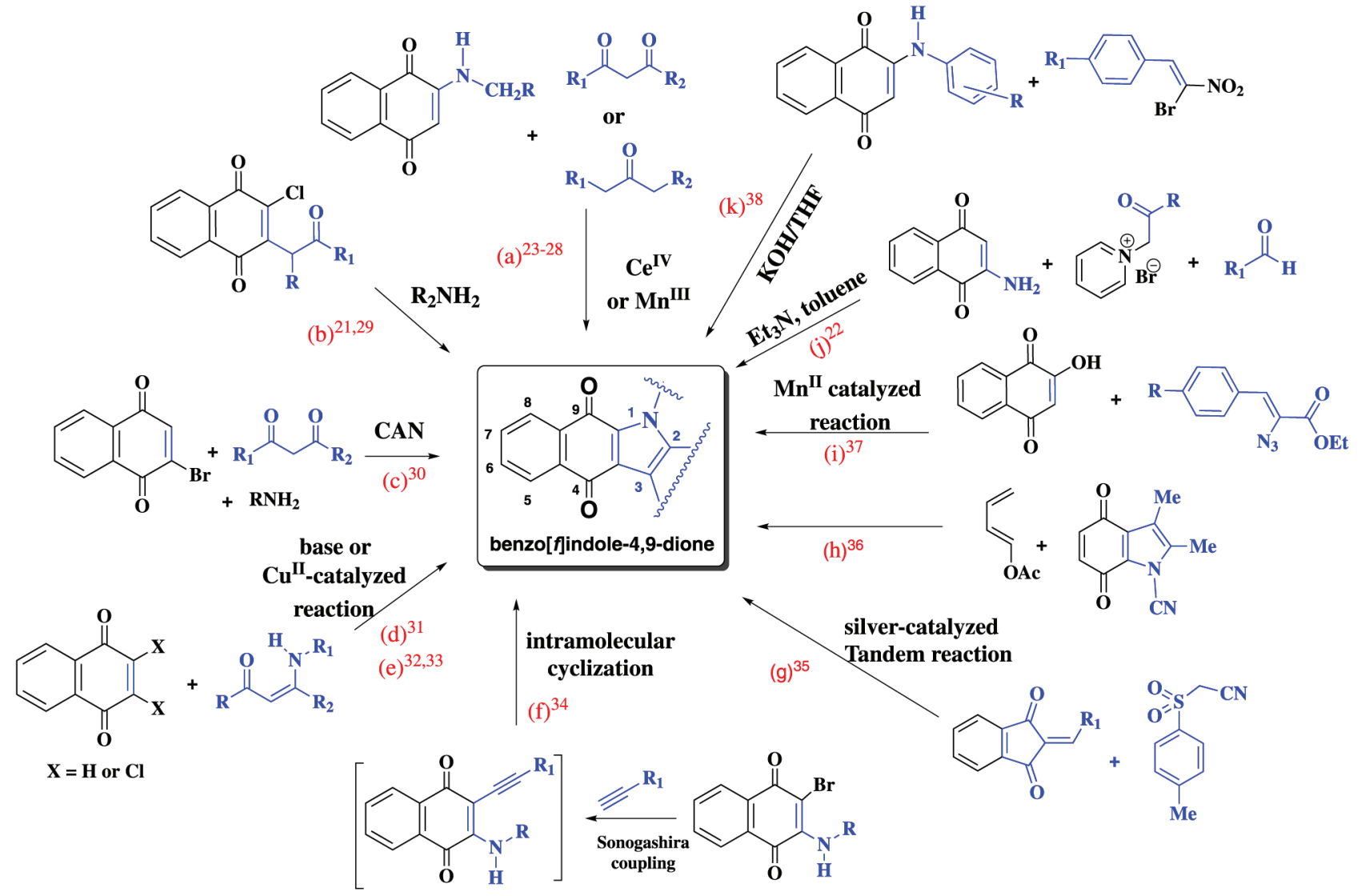

Figure 2. Different methods for the preparation of benzo[f]indole-4,9-dione derivatives. CAN: ceric ammonium nitrate; THF: tetrahydrofuran.
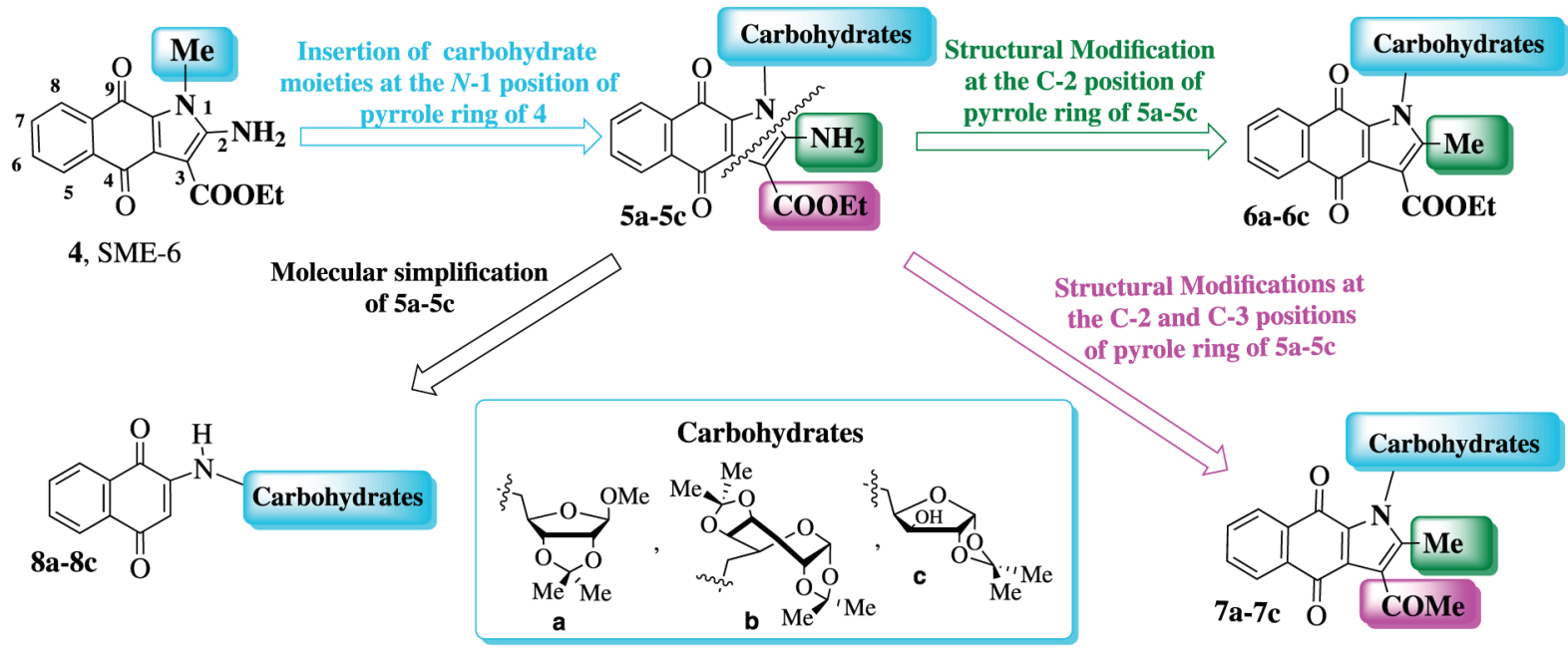

Figure 3. Rational approach to the design of benzo[f]indole-4,9-dione glycoconjugates $\mathbf{5 a - 5 c}, \mathbf{6 a - 6}$ and $\mathbf{7 a - 7 c}$ and 2-amino-1,4-naphthoquinone derivatives 8a-8c.

The ultrasound-accelerated Michael addition type reaction of aminocarbohydrates $\mathbf{9 a - 9 c}$ with 1,4-naphthoquinone (12) produced the corresponding amino sugar quinones 8a-8c (Scheme 2), according to the method outlined in our previous reports ${ }^{41,42}$ (Supplementary Information (SI) section).
The structural characterization of the aminoquinone $\mathbf{8 a - 8 c}$ was performed by using one- and two-dimensional nuclear magnetic resonance (NMR) spectroscopy.

In the ${ }^{13} \mathrm{C}$ NMR spectra of substances $\mathbf{8 a - 8}$, two downfield signals observed at $\delta_{\mathrm{C}} 183.2$ and $181.8(\mathbf{8 a})$, 183.0 and $181.7(\mathbf{8 b})$ and 182.9 and $180.7(\mathbf{8 c})$ were 


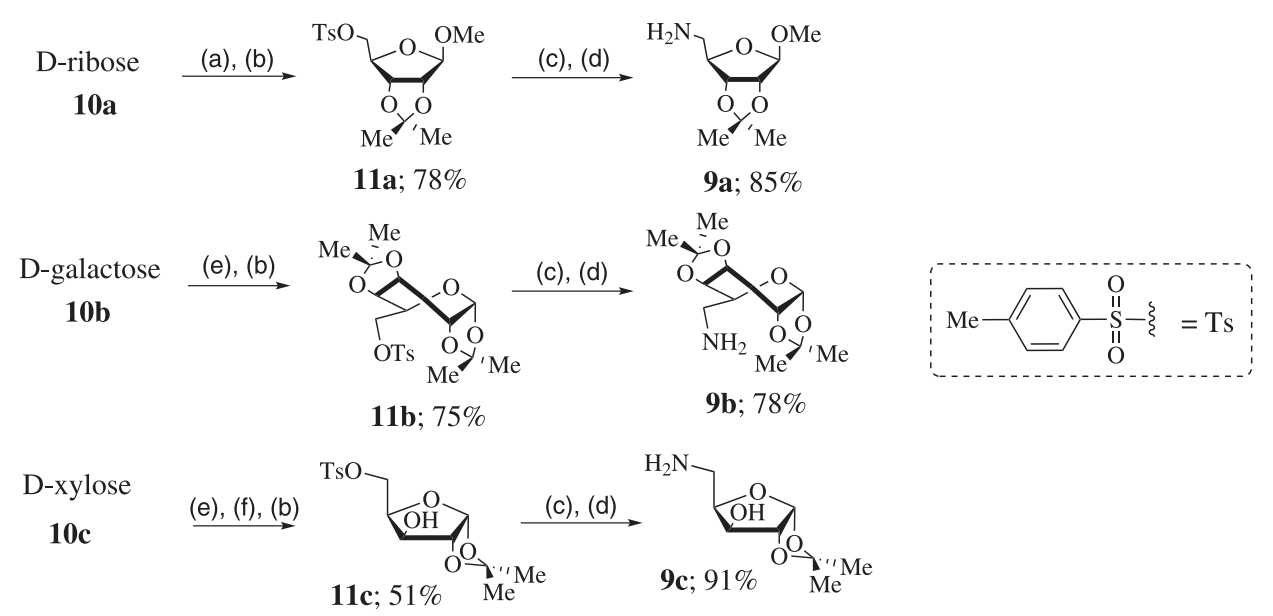

Scheme 1. Preparation of aminocarbohydrate derivatives 9a-9c. (a) Acetone, $\mathrm{H}_{2} \mathrm{SO}_{4}, \mathrm{MeOH}, 25^{\circ} \mathrm{C}, 48 \mathrm{~h}$; (b) pyridine, $\mathrm{TsCl}, 25^{\circ} \mathrm{C}, 20 \mathrm{~h}$; (c) $\mathrm{NaN} / \mathrm{DMF}$, $120^{\circ} \mathrm{C}, 20 \mathrm{~h}$; (d) $\mathrm{Pd} / \mathrm{C}, \mathrm{H}_{2}$, EtOH, $3 \mathrm{~atm}, 3 \mathrm{~h}$; (e) acetone, $\mathrm{H}_{2} \mathrm{SO}_{4}, \mathrm{CuSO}_{4}, 25^{\circ} \mathrm{C}, 24 \mathrm{~h}$; (f) aqueous solution $\mathrm{HCl} 0.2 \%, \Delta, 2 \mathrm{~h}$.
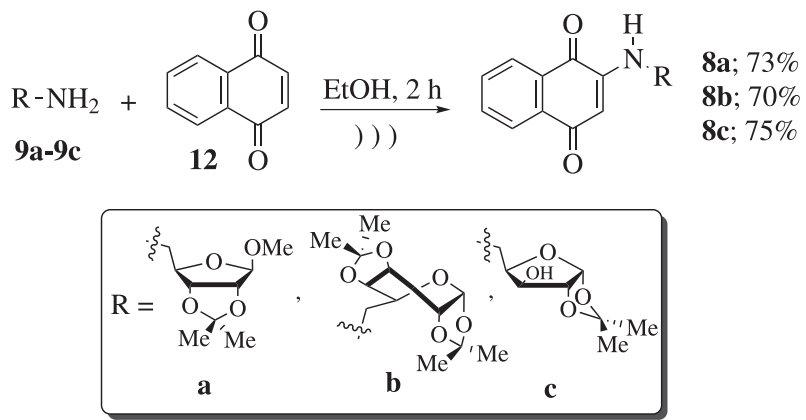

Scheme 2. Preparation of glycoconjugated aminoquinones 8a-8c.

attributed to the carbonyl carbons $\mathrm{C}-1$ and C-4, respectively. The chemical shifts of $\mathrm{C}-1$ and $\mathrm{C}-4$ were differentiated on the basis of the analysis of the resonance effect caused by amino group attached to the $\mathrm{C}-2$ position of the quinone ring, which makes the $\mathrm{C}-4$ carbonyl group less electrophilic. The assignments of these carbons C-1 and C-4 were also supported by heteronuclear multiple bond correlation (HMBC) experiments. In their spectra it was observed long-range correlation $\left({ }^{3} J_{\mathrm{CH}}\right)$ between H-3 and carbonyl carbon C-4 signals.

In the ${ }^{1} \mathrm{H}$ NMR spectra of these substances the doublet of doublets in the range of 8.07-8.10 ppm was attributed to hydrogen $\mathrm{H}-8$, due to its proximity to the more electrophilic carbonyl group (C-1).

In the ${ }^{1} \mathrm{H}-{ }^{1} \mathrm{H}$ correlation spectroscopy (COSY) spectra of 8a-8c, the correlation of the H-8 signal led to assign H-7 hydrogen as the triplet of doublets in the range of 7.68-7.85 ppm. Correlation of this hydrogen led to the subsequent assignment of H-6, allowing, subsequently, the assignment of H-5. The singlet signal between 5.73-5.89 ppm was correlated to $\mathrm{H}-3$.

In the HMBC spectra of $\mathbf{8 a - 8 c}$, long-range correlations $\left.{ }^{3} J_{\mathrm{CH}}\right)$ between C-4a and C-8a and H-6 and $\mathrm{H}-7$ signals support the assignments of these carbons.
Table S1 (SI section) shows ${ }^{1} \mathrm{H}$ and ${ }^{13} \mathrm{C}$ assignments of quinonoid moiety of these compounds $\mathbf{8 a - 8 c}$.

Spectroscopic analysis of the carbohydrate groups of 1,4-naphthoquinone derivatives $\mathbf{8 a - 8} \mathbf{c}$

In the ${ }^{1} \mathrm{H}-{ }^{-1} \mathrm{H}$ COSY spectrum of compound $\mathbf{8 a}$, the methylene signal in the range $3.23-3.33 \mathrm{ppm}(2 \mathrm{H}, \mathrm{m}, \mathrm{H}-5$, and $\mathrm{H}-5$ ") showed correlation to $\mathrm{H}-4$ ' $\left(\delta_{\mathrm{H}} 4.49\right.$, dd, $J 6.0$, $6.0 \mathrm{~Hz}$ ). The ${ }^{1} \mathrm{H}$ NMR spectrum of $\mathbf{8 a}$, the singlet signal of anomeric proton $\mathrm{H}-1$ ' was found at $\delta_{\mathrm{H}} 5.03$. This proton could be easily identified based on the electron-attracting effect caused by two oxygen atoms attached to the carbon of the anomeric position C-1'. Two doublet signals at $\delta_{\mathrm{H}} 4.64(\mathrm{~J} 6.0 \mathrm{~Hz})$ and $4.62(\mathrm{~J} 6.0 \mathrm{~Hz})$ were attributed to corresponding protons $\mathrm{H}-2$ ' and $\mathrm{H}-3$ '. The absence of vicinal coupling indicated a trans relationship between protons $\mathrm{H}-1$ ' and $\mathrm{H}-2$ ' and the $\beta$-anomeric configuration for the sugar ring. Further, in the HMBC spectrum, it was found that protons $\mathrm{H}-1$ ' and $\mathrm{H}-5$ ' $/ \mathrm{H}-5$ 'showed three longrange correlations to quaternary carbon C-3' $(\delta 82.3 \mathrm{ppm})$.

$\mathrm{H}-1$ ' signal of compound $\mathbf{8 b}$ at $\delta_{\mathrm{H}} 5.54(\mathrm{~d}, J 5.0 \mathrm{~Hz})$ showed COSY correlation to $\mathrm{H}_{-2}{ }^{\prime}\left(\delta_{\mathrm{H}} 4.33\right.$, dd, $J 5.0$ and $2.5 \mathrm{~Hz}$ ). The correlation observed between the $\mathrm{H}-2$ ' proton and doubled doublet signal at $\delta_{\mathrm{H}} 4.63(J 8.0,2.5 \mathrm{~Hz})$ permitted the identification of $\mathrm{H}-3$ '. COSY correlations between $\mathrm{H}-4^{\prime} / \mathrm{H}-3^{\prime}, \mathrm{H}-4^{\prime} / \mathrm{H}-5^{\prime}$ ' and between proton $\mathrm{H}-5^{\prime}$ and methylene protons H-6' and H-6" were also observed. The twist-boat conformation of the D-galactose ring in $\mathbf{8 b}$ was confirmed by the ${ }^{1} \mathrm{H}-{ }^{1} \mathrm{H}$ vicinal coupling constants values $J_{\mathrm{H}-\mathrm{l}^{\prime}, \mathrm{H}-2^{2}}, J_{\mathrm{H}-2^{2}, \mathrm{H}-3^{\prime}}, J_{\mathrm{H}-3^{\prime}, \mathrm{H}-4^{\prime}}$ and $J_{\mathrm{H}-4^{\prime}, \mathrm{H}-5^{\prime}}(5.0,2.5,8.0$ and $1.5 \mathrm{~Hz}$, respectively) of the ring protons. ${ }^{40}$

The ${ }^{1} \mathrm{H}-{ }^{1} \mathrm{H}$ COSY spectrum of quinone derivative $\mathbf{8 c}$ showed connectivity among $\mathrm{H}-1$ ' $\left(\delta_{\mathrm{H}} 6.02, J 3.5 \mathrm{~Hz}\right)$ and $\mathrm{H}-2^{\prime}\left(\delta_{\mathrm{H}} 4.61, J 3.5 \mathrm{~Hz}\right)$ protons. The $\mathrm{H}-4$ ' signal at 4.47 
(ddd, $J$ 9.5, 5.0, $3.0 \mathrm{~Hz}$ ) showed COSY correlations to $\mathrm{H}-3^{\prime}\left(\delta_{\mathrm{H}} 4.24, \mathrm{~d}, J 3.0 \mathrm{~Hz}\right)$ and non-equivalent protons H-5' $\left(\delta_{\mathrm{H}} 3.58, \mathrm{dd}, J 15.0,9.5 \mathrm{~Hz}\right)$ and $\mathrm{H}-5$ " $\left(\delta_{\mathrm{H}} 3.67\right.$, dd, $J 15.0,5.0 \mathrm{~Hz})$.

Table S1 (SI section) shows ${ }^{1} \mathrm{H}$ and ${ }^{13} \mathrm{C}$ assignments of sugar groups of the compounds $\mathbf{8 a - 8 c}$.

Synthesis of benzo[ $f$ indole-4,9-dione glycoconjugates $5 a-5 c, 6 a-6 c$ and $7 a-7 c$

The cerium(IV)-mediated oxidative free radical cyclization reaction between 1,4-amino-naphthoquinones 8a-8c and ethyl cyanoacetate (13) (Scheme 3$)^{21}$ resulted in a complex mixture of products in which the ring products 5a-5c could not be identified. However, the polyfunctionalized benzo[f]indole-4,9-diones 6a-6c and $\mathbf{7 a - 7 c}$ were successfully obtained under the same conditions, by reacting the corresponding $\beta$-dicarbonyl compounds 14a-14b with the amino derivatives 8a-8c.

In this reaction, electrophilic intermediates $\mathbf{1 5 a}$ and $\mathbf{1 5 b}$ were produced from the oxidative step with cerium(IV) of the corresponding 1,3-dicarbonyl compounds $14 \mathbf{a}$ and $\mathbf{1 4 b}$, which underwent to an intermolecular addition involving the $\mathrm{C}-\mathrm{C}$ double bond of aminoquinone derivatives 8a-8c followed by a second oxidation step to give $\mathbf{1 6 a - 1 6 c}$ and 17a-17c. These latter substances underwent intramolecular cyclization producing the annulated naphthoquinones $\mathbf{6 a - 6 c}$ and $\mathbf{7 a - 7 c}$, respectively.

An alternative synthetic route to prepare the naphthoquinone compounds 5a-5c (Scheme 4) involved the nucleophilic substitution reaction between 2,3-dichloronaphthoquinone (20) $)^{21}$ with ethyl cyanoacetate carbanion, formed in situ by reaction of ethyl cyanoacetate (21) with potassium carbonate.

The formation of the glycoconjugated quinones $\mathbf{5 a - 5 c}$ can be rationalized from compound $\mathbf{2 2}$ which results from the replacement of a chlorine atom of 20. The nucleophilic substitution of the second chlorine atom by aminocarbohydrates $\mathbf{9 a - 9 c}$ leads to the intermediate 23a-23c which spontaneously cyclize and then tautomerize to the respective glycoconjugated quinones $\mathbf{5 a - 5 c}$ (Scheme 4).

In the ${ }^{13} \mathrm{C}$ NMR spectra of substances $5 \mathbf{a}-\mathbf{5 c}, \mathbf{6 a - 6}$ and 7a-7c, the chemical shifts of the C-4 and C-9 carbonyl carbons were attributed based on those of the corresponding carbons in the spectra of the quinones $\mathbf{8 a - 8 c}$ and also on

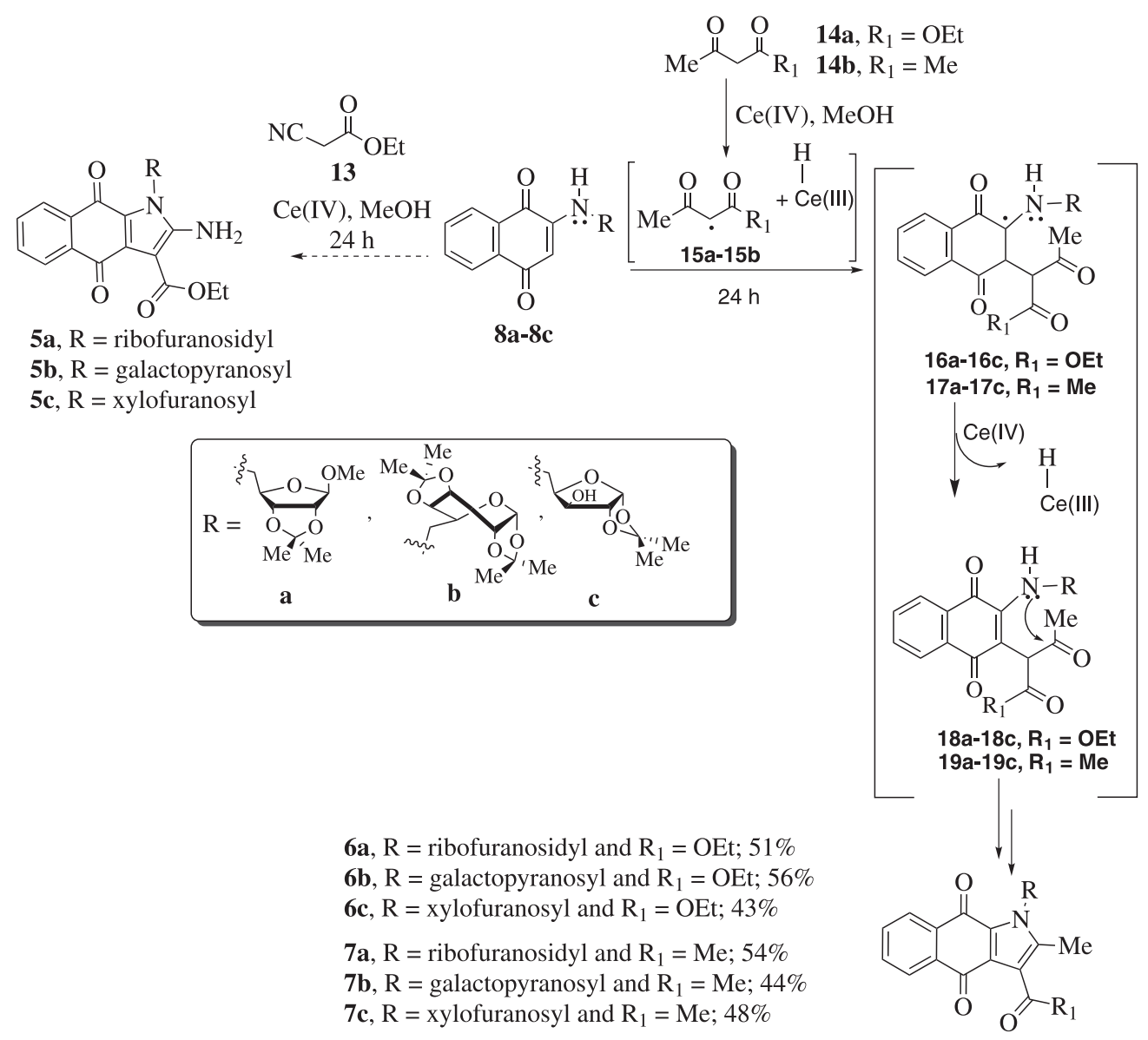

Scheme 3. The synthetic routes used to prepare the annulated quinones 6-7. 


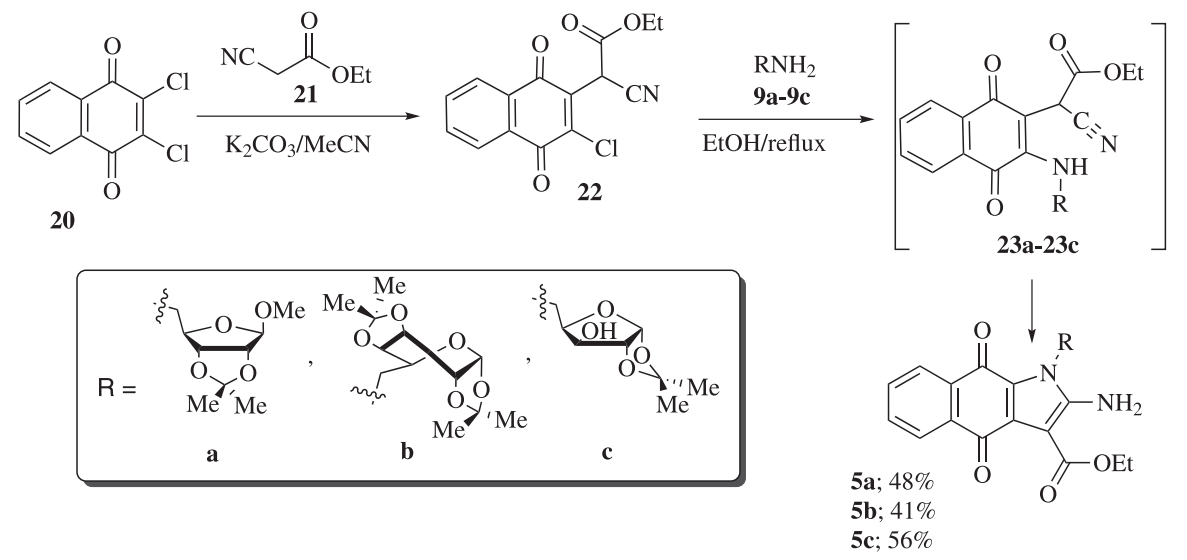

Scheme 4. Preparation of benzo[f]indole-4,9-dione derivatives 5a-5c.

long range correlations observed in their $\mathrm{HMBC}$ spectra (Tables S2, S3, S4, in the SI section). In HMBC spectra of $5 \mathbf{a}-5 \mathbf{c}, 6 \mathbf{6}-\mathbf{6 c}$ and $7 \mathbf{a}-7 \mathbf{c}$ the hydrogens H-5 correlated with the C-4 $\left({ }^{3} J_{\mathrm{CH}}\right)$ carbon signals and these latter showed correlation to $\mathrm{H}-5$ signals $\left({ }^{2} J_{\mathrm{CH}}\right)$.

The long-range correlations ${ }^{2} J_{\mathrm{CH}}$ and ${ }^{3} J_{\mathrm{CH}}$ of the C-2 carbon with the methylene and methyl hydrogens of the carbohydrate groups (Tables S2, S3, S4 in the SI section) clearly confirmed the presence of the fused pyrrolic ring to the naphthoquinone framework. The HMBC spectra were also important for the assignment of C-9a carbon. ${ }^{1} \mathrm{H}$ and ${ }^{13} \mathrm{C}$ NMR data of quinone derivatives 5a-5c, 6a-6c and 7a-7c are listed in Tables S2, S3 and S4 (SI section).

\section{Biological analysis}

The cancer cell lines used in this study were MCF-7 (human mammary gland/breast epithelial adenocarcinoma); MDA-MB 231 (human mammary gland/breast epithelial adenocarcinoma); A549 (human lung carcinoma); HT-29 (human epithelial colorectal adenocarcinoma); Hep G2 (human liver hepatocellular carcinoma); SH-SY5Y (human bone marrow neuroblastoma); HT-1080 (human connective tissue epithelial fibrosarcoma) and DMS 79 (human lung pleural fluid carcinoma) and normal human blood peripheral leukocytes and erythrocytes. The compounds 5a-5c, 6a-6c, 7a-7c and 8a-8c were tested in vitro by the MTT (3-(4,5-dimethyl-2-thiazyl)-2,5-diphenyl$2 \mathrm{H}$-tetrazolium bromide) assay to evaluate the cytotoxicity after $24 \mathrm{~h}$ of treatment. Lytic effect was evaluated against human erythrocytes. Doxorubicin (an antitumor drug) was used as positive control. Data is expressed as concentration that induced $50 \%$ cytotoxic effect $\left(\mathrm{IC}_{50}\right)$ (Table 1$)$.

The compounds were classified according to their activity as highly active $\left(\mathrm{IC}_{50}<2 \mu \mathrm{M}\right)$, moderately active $\left(2 \mu \mathrm{M}<\mathrm{IC}_{50}<10 \mu \mathrm{M}\right)$ or inactive $\left(\mathrm{IC}_{50}>10 \mu \mathrm{M}\right){ }^{43}$
The quinone glycoconjugates $5 \mathbf{5}-5 \mathbf{c}, 6 \mathbf{6}-\mathbf{6 c}, 7 \mathbf{7}-7 \mathbf{c}$ and 8a-8c (Table 1) did not exhibit any lytic effects against normal human erythrocytes or leukocytes. Among the pyrrolo-annelated naphthoquinones $\mathbf{5 a - 5 c}$, only derivatives 5b-5c showed selective cytotoxicity against MCF-7 and A549 cancer cell lines, respectively, with $\mathrm{IC}_{50}$ values of 9.7 and $8.8 \mu \mathrm{M}$, respectively (Table 1 ).

The nature of the substituents attached to the pyrrole nucleus influenced the antitumor activity of the naphthoquinone derivatives $5 \mathbf{5}-\mathbf{5 c}, \mathbf{6 a - 6} \mathbf{c}$ and $\mathbf{7 a - 7 c}$. It was observed that the replacement of a free primary amino group at C-2 position of the pyrrole ring of $\mathbf{5 a}-\mathbf{5 b}$ by methyl group made the naphthoquinone derivatives $\mathbf{6 a - 6} \mathbf{b}$ more cytotoxic than the related parent compounds against three tumor cell lines (Table 1). These results suggest that the hydrophobic effect of methyl group attached to the naphthoquinone nucleus of substances $\mathbf{6 a}$ and $\mathbf{6 b}$ plays an important role for improvement of their potency and broader their spectrum of antitumor activity.

For derivative $\mathbf{6 c}$, the presence of a methyl group attached at $\mathrm{C}-2$ position of the pyrrole ring resulted in the loss of antitumor activity, while its analogous compound $\mathbf{5 c}$ exhibited selective cytotoxicity against A549 cell lines. The compounds 7a-7c bearing acetyl group at the $\mathrm{C}-3$ position of the pyrrole ring did not cause any cytotoxic effect on all cell lines tested.

Among the carbohydrate-based 1,4-naphthoquinones $\mathbf{8 a - 8 c}$, only amino derivative 8a displayed selective cytotoxicity toward MDA-MB 231 cell line, with an $\mathrm{IC}_{50}$ value of $8.9 \mu \mathrm{M}$. The antitumor activity of this compound can be related to the chemical properties (e.g., conformation and intermolecular interactions) of the ribofuranosyl ring. Major number of annelated glycoconjugated compounds displayed better cytotoxicity than 2-amino1,4-naphthoquinones glycoconjugates. In addition, the series of quinones $6 \mathbf{6}-\mathbf{6 b}$ displayed greater activity in three tested cancer cell lines than their parent compounds. It is 
Table 1. Cytotoxicity expressed as 50\% cytotoxic effect $\left(\mathrm{IC}_{50}\right)$ of compounds $\mathbf{5 a - 5} \mathbf{c}, \mathbf{6 a - 6} \mathbf{c}, \mathbf{7 a - 7} \mathbf{c}$ and $\mathbf{8 a - 8}$ against different cell lines

\begin{tabular}{|c|c|c|c|c|c|c|c|c|c|c|}
\hline \multirow[b]{2}{*}{ Compound } & \multicolumn{10}{|c|}{$\mathrm{IC}_{50} / \mu \mathrm{M}$} \\
\hline & MCF-7 & MDA-MB 231 & A549 & HT-29 & HepG2 & SH-SY5Y & HT-1080 & DMS 79 & $\begin{array}{l}\text { Human blood } \\
\text { leukocyte }\end{array}$ & Erythrocyte $^{\mathrm{a}}$ \\
\hline $5 \mathbf{a}$ & $>30$ & 22.4 & 20.9 & 18.8 & 17.9 & $>30$ & 21.1 & 17.0 & $>100$ & $>150$ \\
\hline $5 b$ & 9.7 & $>30$ & 12.7 & 21.8 & 29.6 & $>30$ & 15.7 & 13.8 & $>100$ & $>150$ \\
\hline $5 c$ & 11.9 & $>30$ & 8.8 & 18.7 & 14.8 & $>30$ & 21.1 & 12.1 & $>100$ & $>150$ \\
\hline $6 a$ & 9.9 & $>30$ & 5.4 & 6.3 & 11.8 & 28.4 & 15.6 & 11.1 & $>100$ & $>150$ \\
\hline $6 \mathbf{b}$ & 9.9 & $>30$ & 6.8 & 11.6 & 19.6 & 13.5 & 27.7 & 7.7 & $>100$ & $>150$ \\
\hline $6 c$ & $>30$ & $>30$ & $>30$ & $>30$ & $>30$ & $>30$ & $>30$ & $>30$ & $>100$ & $>150$ \\
\hline $7 \mathbf{a}$ & 27.8 & $>30$ & 21.8 & 22.6 & 20.3 & $>30$ & 20.4 & 21.7 & $>100$ & $>150$ \\
\hline $7 b$ & $>30$ & 28 & 25.4 & 28.8 & 21.3 & $>30$ & 22.5 & 22.9 & $>100$ & $>150$ \\
\hline $7 c$ & $>30$ & $>30$ & $>30$ & $>30$ & $>30$ & $>30$ & $>30$ & $>30$ & $>100$ & $>150$ \\
\hline $8 \mathbf{a}$ & 25.6 & 8.9 & 13.8 & 19.4 & 17.7 & $>30$ & 20 & 21.7 & $>100$ & $>150$ \\
\hline $8 b$ & $>30$ & $>30$ & 20.4 & 18.8 & 13.4 & $>30$ & $>30$ & 17.7 & $>100$ & $>150$ \\
\hline $8 c$ & $>30$ & 18.9 & 23.6 & 27.5 & 17.7 & $>30$ & 29.9 & 13.8 & $>100$ & $>150$ \\
\hline Doxorubicin $^{\mathrm{b}}$ & 1.8 & 0.7 & 0.47 & 0.33 & 0.58 & 0.77 & 1.1 & 0.08 & 3.41 & $>25$ \\
\hline
\end{tabular}

${ }^{a}$ Concentration of compound that induced erythrocyte lysis; bdoxorubicin was used as positive control. Only compounds with an $\mathrm{IC}_{50}$ value lower than $10 \mu \mathrm{M}$ for at least one cell line were considered active; Data are presented as $\mathrm{IC}_{50}$ values obtained by nonlinear regression for all cell lines from three independent experiments. MCF-7: human mammary gland/breast epithelial adenocarcinoma; MDA-MB 231: human mammary gland/breast epithelial adenocarcinoma; A549: human lung carcinoma; HT-29: human epithelial colorectal adenocarcinoma; Hep G2: human liver hepatocellular carcinoma; SH-SY5Y: human bone marrow neuroblastoma; HT-1080: human connective tissue epithelial fibrosarcoma; DMS 79: human lung pleural fluid carcinoma.

noteworthy that the compounds $\mathbf{6 a - 6} \mathbf{b}$ can serve as available inspiration in the search for new effective antitumoral agents.

It is well-known that the cytotoxic assay, MTT, is considered a metabolic assay and can result in variable results. ${ }^{43}$ The morphology-based evaluation of viability/ cytotoxicity by phase-contrast microscopy and DAPI (4',6-diamidino-2-phenylindole) staining are greatly useful to explain the apoptotic effects.

Breast cancer is composed of multiple subtypes, with distinct morphologies and clinical implications, including triple-negative breast cancer (TNBC), which refers to estrogen receptor, progesterone receptor and HER2 (human epidermal growth factor receptor-type 2) negative. Without available targeted therapy options, the standard of care for TNBC remains chemotherapy. The recurrence and mortality in the TNBC is significantly higher than the other subtypes. ${ }^{44}$ Many TNBC exhibit resistance to chemotherapy and all metastatic TNBC eventually develop resistance. ${ }^{45}$ Han et al. ${ }^{46}$ showed that chemoresistance can be acquired rapidly in MDA-MB 231 cells under a doxorubicin concentration gradient. So we decided to investigate the potential apoptotic effects of four synthesized compounds, $\mathbf{5 b}, \mathbf{5 c}, \mathbf{6 a}$ and $\mathbf{6 b}$ in MDA-MB 231, a TNBC cell line.

The apoptogenic property of the compounds was verified through the analysis of morphological changes in MDA-MB 231 cells. Apoptotic cells exhibit typical features such as nuclear condensation, cytoplasm shrinkage, membrane blebs, formation of pyknotic bodies (this is the most characteristic feature of apoptosis) and energydependent biochemical mechanisms. ${ }^{47}$

After incubation with tested compounds for $24 \mathrm{~h}$, morphological alterations in MDA-MB 231 cells were observed (Figure 4) in comparison to control cells. $0.5 \mu \mathrm{M}$ doxorubicin (1) was used as positive control. Visualization of the control (untreated) cells showed that the cells maintained their original morphology form. In contrast, exposure of MDA-MB 231 cells treated with $30 \mu \mathrm{M}$ of compounds $\mathbf{5 b}, \mathbf{5 c}, \mathbf{6 a}$ and $\mathbf{6 b}$ for $24 \mathrm{~h}$ revealed typical apoptotic features such as shrinkage, membrane blebbing, and losing contact with adjacent cells, which can also be seen in the positive control.

Apoptotic cells were defined exhibiting condensed chromatin and fragmented nuclei, while nonapoptotic cells showed a fine network of chromatin in the entire nuclear area. To examine whether the cytotoxicity of these compounds was mediated through apoptosis, MDA-MB 231 cells treated with $30 \mu \mathrm{M}$ of the selected compounds for $24 \mathrm{~h}$ were stained with DAPI, and the appearance of chromatin condensation and fragmentation of nuclei were analyzed (Figure 5). The morphological observation in the cell nuclei of MDA-MB 231 with or without tested compounds showed significant morphological alterations when compared to untreated control. $0.5 \mu \mathrm{M}$ doxorubicin (1) was used as 

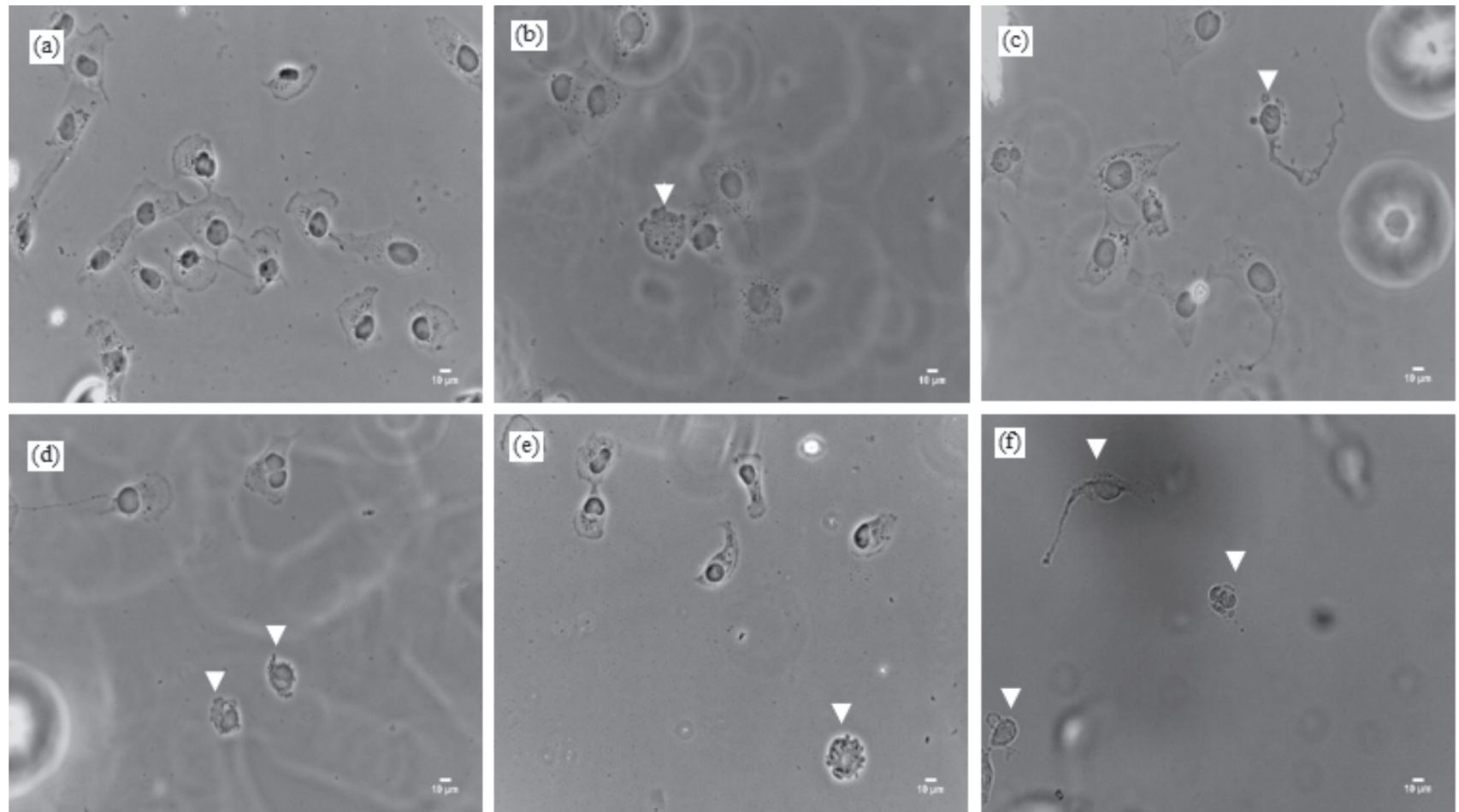

Figure 4. Morphological changes of MDA-MB 231 (human mammary gland/breast epithelial adenocarcinoma) cells. (a) Nontreated, control cells; and treated cells $(30 \mu \mathrm{M}$ ) with compounds (b) $\mathbf{5 b}$; (c) $\mathbf{5 c}$; (d) $\mathbf{6 a}$; (e) $\mathbf{6 b}$ and (f) $0.5 \mu \mathrm{M}$ doxorubicin (1) for $24 \mathrm{~h}$ and imaged by phase-contrast microscope (magnification 40x). Arrows indicate apoptotic bodies.

positive control. No apoptotic nuclei were observed in control cells (Figure 5a) and apoptotic nuclei, indicated by arrows, were significantly increased in cells exposed to $30 \mu \mathrm{M}$ of the compounds (Figures $5 \mathrm{~b}, 5 \mathrm{c}, 5 \mathrm{~d}, 5 \mathrm{e}$ ). The results indicate that these four compounds induce apoptotic cell death in MDA-MB 231 cells.
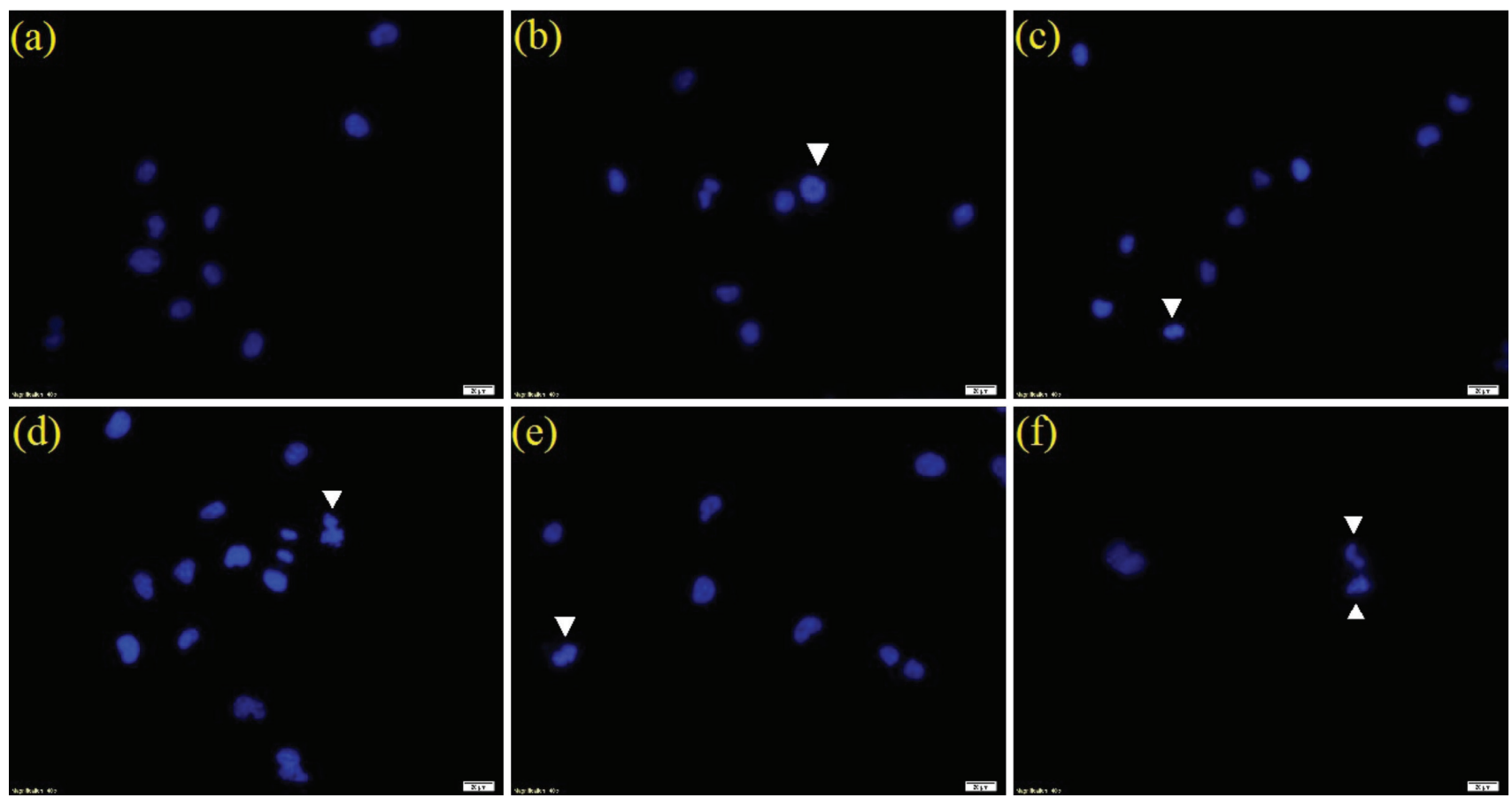

Figure 5. Representative images show morphological changes of MDA-MB 231 (human mammary gland/breast epithelial adenocarcinoma) cells detected with DAPI (4',6-diamidino-2-phenylindole) staining. (a) Nontreated, control cells; and treated cells (30 $\mu \mathrm{M}$ ) with compounds (b) 5b; (c) 5c; (d) 6a; (e) 6b and (f) $0.5 \mu \mathrm{M}$ doxorubicin (1) for $24 \mathrm{~h}$ and imaged by fluorescence microscope (magnification $40 \mathrm{x}$ ). Arrows indicate live cells with apoptotic nuclei. 
All bioactive compounds were found to be less cytotoxic active against cancer cells than the clinically useful anticancer agent doxorubicin. Although doxorubicin is considered an important drug for the chemotherapy, it has several clinical limitations, such as cardiotoxic effects and a high incidence of multi-drug resistance. ${ }^{48}$ Furthermore, the normal cells, erythrocytes, were more sensitive to treatment with doxorubicin (1), reducing cell viability with lower concentrations, than with all the test compounds, suggesting that the effect of these test compounds was selected for cancer cell lines.

\section{Conclusions}

In summary, three classes of benzo[f $f$ indole-4,9-dione glycoconjugates $\mathbf{5 a - 5 c}, \mathbf{6 a - 6}$ and $\mathbf{7 a - 7 c}$ and aminonaphthoquinones 8a-8c have been synthesized and evaluated for antitumoral activity against eight human cancer cell lines. None of these compounds exhibited lytic effects against normal human erythrocytes or leukocytes. The compounds $\mathbf{5 b}-\mathbf{5} \mathbf{c}, \mathbf{6 a}-\mathbf{6} \mathbf{b}$ and $\mathbf{8 a}$ exhibited significant cytotoxic activity. The quinone derivatives bearing carbetoxy moiety at the position of pyrrole ring $\mathbf{6 a - 6} \mathbf{b}$ were the most potent of these families, with $\mathrm{IC}_{50}$ values below $7.8 \mu \mathrm{M}$ against two tumor cell lines. The influence of carbohydrates can be better evidenced for the series 6a-6c. The enhanced anticancer activity of $\mathbf{6 a - 6} \mathbf{b}$ in most of the tested cancer cell lines may be related to the chemical structures (e.g., conformation and intermolecular interactions) of the corresponding furanose and pyranose rings. The derivatives $\mathbf{6 a - 6} \mathbf{b}$ can be considered as promising lead compounds for the development of more potent anticancer agents. Furthermore, morphological analysis using phase contrast microscope and DAPI staining procedures by fluorescence microscope indicate that the compounds $\mathbf{5 b}, \mathbf{5 c}, \mathbf{6 a}$ and $\mathbf{6 b}$ were able to trigger cell death of triple negative breast cancer cells, MDA-MB 231, through apoptosis. Nevertheless, further investigations are necessary to validate its therapeutic claims and to determine the mode of action of these compounds.

\section{Experimental}

\section{Cell culture}

Compounds $(0.15-30 \mu \mathrm{M})$ were tested for cytotoxic activity against MCF-7 (human mammary gland/breast epithelial adenocarcinoma, American Type Culture Collection (ATCC) No. HTB-22), A549 (human lung carcinoma, ATCC No. CCL-185), MDA-MB 231 (human mammary gland/breast epithelial adenocarcinoma,
ATCC No. HTB-26), HT-29 (human epithelial colorectal adenocarcinoma, ATCC No. HTB-38), Hep G2 (human liver hepatocellular carcinoma, ATCC No. HB-8065), SH-SY5Y (human bone marrow neuroblastoma, ATCC No. CRL-2266), HT-1080 (human connective tissue epithelial fibrosarcoma, ATCC No. CCL-212), DMS 79 (human lung pleural fluid carcinoma, ATCC No. CRL-2049), freshly prepared human blood leukocytes and erythrocytes. All cell lines were maintained in Roswell Park Memorial Institute (RPMI) 1640 medium supplemented with $10 \%$ fetal bovine serum (FBS), $2 \mathrm{mM}$ glutamine, $100 \mathrm{U} \mathrm{mL}^{-1}$ penicillin and $100 \mathrm{mg} \mathrm{mL}^{-1}$ streptomycin at $37{ }^{\circ} \mathrm{C}$ with $5 \% \mathrm{CO}_{2}$. Media were changed every two or three days.

\section{Cytotoxic assay}

Cell viability was determined using 3-(4,5-dimethyl2-thiazyl)-2,5-diphenyl-2H-tetrazolium bromide (MTT) reagent (Sigma-Aldrich, Massachusetts, USA). Briefly, cells were plated at an initial density of $2.5 \times 10^{4}$ cells per well in 96-well plates and incubated for $24 \mathrm{~h}$ at $37^{\circ} \mathrm{C}$ and $5 \% \mathrm{CO}_{2}$. After $24 \mathrm{~h}$ cultures were treated with the compounds $(0.15-30 \mu \mathrm{M})$ and further incubated for $24 \mathrm{~h}$. Each compound was dissolved with dimethyl sulfoxide (DMSO) and diluted with cell culture medium to obtain a concentration of $100 \mu \mathrm{M}$. The negative control received the same amount of DMSO $(0.005 \%$ in the highest concentration). Doxorubicin (1) was used as a positive control. After treatment, the supernatant of each well was removed, and cells were washed twice with medium. Then, $10 \mu \mathrm{L}$ of MTT solution ( $5 \mathrm{mg} \mathrm{mL}^{-1}$ in RPMI) and $100 \mu \mathrm{L}$ of medium were added to each well and incubated for $3 \mathrm{~h}$ at $37^{\circ} \mathrm{C}, 5 \% \mathrm{CO}_{2}$, as described by Denizot and Lang. ${ }^{49}$ The resultant formazan crystals were dissolved in dimethyl sulfoxide $(100 \mu \mathrm{L})$ and absorbance intensities were measured in a microplate reader (FlexStation Reader, Molecular Devices, USA) at $570 \mathrm{~nm}$. All experiments were performed in triplicate.

\section{Erythrocytes hemolysis}

The test was performed as adapted from Malagoli, ${ }^{50}$ in 96-well plates using a $2 \%$ human erythrocyte suspension in $0.85 \% \mathrm{NaCl}$ containing $10 \mathrm{mM} \mathrm{CaCl}_{2}$. The compounds diluted as mentioned above were tested at concentration of $150 \mu \mathrm{M}$. After incubation at room temperature for $30 \mathrm{~min}$ and centrifugation, the supernatant was removed, and the liberated hemoglobin was measured spectrophotometrically at $540 \mathrm{~nm}$. DMSO was used as a negative control and Triton X-100 (1\%) was used as positive control. 
Cell morphological assessment of apoptosis

Cultured cells, MDA-MB 231, were incubated for $24 \mathrm{~h}$ with or without selected compounds at concentrations of $30 \mu \mathrm{M}$ in a 12-wells plate cell culture dishes, were fixed with $2 \%$ formaldehyde in phosphate buffered saline (PBS) for $3 \mathrm{~min}$ after washing with $\mathrm{PBS}$ at $37^{\circ} \mathrm{C}$. The morphological changes of the apoptotic cells were observed using phase contrast microscope (Leica DMI 3000B, Germany) at $40 \times$ magnification.

\section{Nuclei morphological changes}

MDA-MB 231 cells were grown on cell culture dishes and treated with or without tested compounds at concentration of $30 \mu \mathrm{M}$. After $24 \mathrm{~h}$, the cells were washed with cold PBS. The cells were fixed with $2 \%$ formaldehyde in PBS for 3 min after washing with PBS at $37^{\circ} \mathrm{C}$. Cells were permeabilized with $0.5 \%$ Triton X-100 in PBS for 10 min, three times. Nuclei were labelled with DAPI $\left(0.1 \mu \mathrm{g} \mathrm{mL} \mathrm{mL}^{-1}\right.$ in $\left.0.9 \% \mathrm{NaCl}\right)$ and cells were mounted in ProLong Gold antifade reagent (Molecular Probes, Eugene, Oregon, USA) and examined with an Axiovert 100 microscope (Carl Zeiss, Germany). Images were acquired with an Olympus DP71 digital camera (Olympus, Japan). Image processing was performed using Fiji software (based on ImageJ). ${ }^{51}$

\section{Chemistry}

Melting points (mp) were determined with a FisherJohns instrument and are uncorrected. Infrared (IR) spectra were recorded on PerkinElmer FT-IR, model 1600 series spectrophotometer in $\mathrm{KBr}$ pellets. NMR spectra were obtained in $\mathrm{CDCl}_{3}$ or $\mathrm{CD}_{3} \mathrm{OD}$ (Sigma-Aldrich, São Paulo, Brazil) using a Varian Unity Plus $500 \mathrm{MHz}$ spectrometer. Chemical shifts $(\delta)$ are expressed in ppm and the coupling constant $(J)$ in hertz. Column chromatography was performed on silica gel flash from Merck (Darmstadt, Germany). Reactions were routinely monitored by thin layer chromatography (TLC) on silica gel pre-coated F254 Merck plates. Microanalyses were performed using a PerkinElmer model 2400 instrument and all values were within $\pm 0.4 \%$ of the calculated compositions.

Synthesis of aminocarbohydrate $9 \mathbf{a}-9 \mathbf{c}$ and 2-amino1,4-naphthoquinones $\mathbf{8 a - 8 c}$

Aminocarbohydrate 9a-9c were prepared from their corresponding commercially available reagents D-ribose (10a), D-galactose (10b) and D-xylose (10c) using previously described methods for carbohydrate derivatization. ${ }^{9,39}$ The general procedure for the synthesis of the aminonaphthoquinones derivatives $\mathbf{8 a - 8} \mathbf{c}$ has been performed according to Franco et al. ${ }^{41}$

\section{Preparation of benzo[f]indole-4,9-diones $\mathbf{6 a - 6 c}$ and $7 \mathbf{a}-7 \mathbf{c}$}

In a $50 \mathrm{~mL}$ round bottom flask were added $0.064 \mathrm{mmol}$ of the 2-amino-1,4-naphtoquinone 8a-8c, $2.56 \mathrm{mmol}$ of active methylene compound (12a-12b), $10 \mathrm{~mL}$ of ethanol, $2 \mathrm{~mL}$ of dichloromethane and $2 \mathrm{~mL}$ of distilled water. Ceric sulfate ( $315 \mathrm{mg}, 5 \mathrm{mmol}$ ) was added to the reaction mixture over a $2 \mathrm{~h}$ period. The reaction medium was kept under continuous stirring for $24 \mathrm{~h}$ at room temperature. Monitoring the reaction by TLC was performed using hexane:ethyl acetate (7:3) as the eluent. Compounds 6a-6c and $\mathbf{7 a - 7 c}$ were detected by a spray reagent consisting of $1 \%\left(\mathrm{~m} \mathrm{v}^{-1}\right)$ vanillin with sulfuric acid after gentle heating or by viewing under short-wave UV light (254 nm). The mixture was filtered through a Buchner funnel and the filtrate was treated with saturated solution of sodium bisulfite. The organic phase was extracted with dichloromethane and dried with anhydrous sodium sulfate. The solvent was evaporated under reduced pressure and the crude product was purified by chromatography on a silica gel column, using a gradient elution of $90-70 \%(\mathrm{v} / \mathrm{v})$ hexane in ethyl acetate.

2-Methyl-1-(methyl-5'-deoxy-2',3'-O-isopropylidene$\beta$-D-methylfuranosid-5'-yl)-4,9-dioxo-4,9-dihydro$1 \mathrm{H}$-benzo[f]indole-3-ethyl carboxylate (6a)

The compound $\mathbf{6 a}$ was obtained as a yellow solid, mp 144-145 ${ }^{\circ} \mathrm{C}$, with $51 \%$ yield. IR ( $\mathrm{KBr}$ pellets) $\mathrm{v} / \mathrm{cm}^{-1}$ 1683 and $1601(\mathrm{C}=\mathrm{O}), 1567(\mathrm{C}=\mathrm{C}) ;{ }^{1} \mathrm{H} \mathrm{NMR}(500.00 \mathrm{MHz}$, $\left.\mathrm{CDCl}_{3}\right) \delta 1.27\left(\mathrm{~s}, 3 \mathrm{H}, \mathrm{CH}_{3}\right), 1.43\left(\mathrm{~s}, 3 \mathrm{H}, \mathrm{CH}_{3}\right), 1.44(\mathrm{t}, 3 \mathrm{H}$, J 7.1 Hz, $\left.\mathrm{CH}_{2}-\mathrm{CH}_{3}\right), 2.54$ (s, 3H, $\left.\mathrm{C}_{2}-\mathrm{CH}_{3}\right), 3.45$ (s, 3H, $\mathrm{OCH}_{3}$ ), 4.29 (dd, 1H, J 15.0, 5.0 Hz, H-5"), 4.44 (q, 2H, $J 7.1 \mathrm{~Hz}, \mathrm{CH}_{2}-\mathrm{CH}_{3}$ ), 4.50 (dd, $\left.1 \mathrm{H}, J 10.0,5.0 \mathrm{~Hz}, \mathrm{H}-4^{\prime}\right)$, 4.73 (d, 1H, J 5.0 Hz, H-3'), 4.78 (d, 1H, J 5.0 Hz, H-2'), 5.03 (s, 1H, H-1'), 5.05 (dd, 1H, J 15.0, 10.0 Hz, H-5'), 7.66-7.67 (m, 1H, H-7), 7.67-7.68 (m, 1H, H-6), 8.13-8.15 (m, 1H, H-5), 8.16-8.17 (m, 1H, H-8); ${ }^{13} \mathrm{C}$ NMR APT (attached proton test) $\left(125.0 \mathrm{MHz}, \mathrm{CDCl}_{3}\right) \delta 11.0$ $\left(\mathrm{C}_{2}-\underline{\mathrm{CH}}_{3}\right), 14.1\left(\mathrm{CH}_{2}-\underline{\mathrm{C}} \mathrm{H}_{3}\right), 24.9\left(\underline{\mathrm{CH}}_{3}\right), 26.4\left(\underline{\mathrm{CH}}_{3}\right), 47.9$ (C-5'), $55.6\left(\mathrm{OCH}_{3}\right), 61.1\left(\underline{\mathrm{CH}}_{2}-\mathrm{CH}_{3}\right), 81.6\left(\mathrm{C}-3^{\prime}\right), 85.2$ (C-2'), 85.5 (C-4'), 110.4 (C-1'), 112.7 (-OCCO-), 114.6 (C-3), 126.2 (C-3a), 126.3 (C-5), 126.6 (C-8), 129.9 (C-9a), 132.9 (C-6), 133.0 (C-4a), 133.3 (C-7), 133.6 (C-8a), 141.8 (C-2), $164.3\left(\underline{\mathrm{C}}=\mathrm{OOCH}_{2}-\mathrm{CH}_{3}\right), 176.2$ (C-4), 179.2 (C-9); anal. calcd. for $\mathrm{C}_{25} \mathrm{H}_{27} \mathrm{NO}_{8}$ : C 63.96, H 5.89, N 2.98, found: C 63.09, H 6.29, N 3.26\%. 
2-Methyl-4-[(6'-deoxy-1',2':3', 4'-di-O-isopropylideneD-galactopiranos-6'-yl)methyl]-4,9-dioxo-4,9-dihydro$1 \mathrm{H}$-benzo[f]indole-3-ethyl carboxylate (6b)

The compound $\mathbf{6 b}$ was obtained as a yellow solid, mp $138-140{ }^{\circ} \mathrm{C}$, with $56 \%$ yield. IR (film) $\mathrm{v} / \mathrm{cm}^{-1} 1609$ and $1678(\mathrm{C}=\mathrm{O}), 1572(\mathrm{C}=\mathrm{C}) ;{ }^{1} \mathrm{H}$ NMR $\left(500.00 \mathrm{MHz}, \mathrm{CDCl}_{3}\right)$ $\delta 1.15$ (s, $\left.3 \mathrm{H}, \mathrm{C}_{3}\right), 1.18$ (s, $\left.3 \mathrm{H}, \mathrm{C}_{3}\right), 1.37$ (s, 3H, $\underline{\mathrm{C}}_{3}$ ), $1.41\left(\mathrm{t}, 3 \mathrm{H}, J 7.1 \mathrm{~Hz}, \mathrm{CH}_{2}-\mathrm{C}_{3}\right), 1.50\left(\mathrm{~s}, 3 \mathrm{H}, \mathrm{CH}_{3}\right), 2.49$ (s, $\left.3 \mathrm{H}, \mathrm{C}_{2}-\mathrm{CH}_{3}\right), 4.24$ (dt, $1 \mathrm{H}, J 9.5,2.5 \mathrm{~Hz}, \mathrm{H}-5$ '), 4.26 (dd, $1 \mathrm{H}, J$ J $.0,2.5 \mathrm{~Hz}, \mathrm{H}-2$ '), 4.32 (dd, 1H, J 14.0, 9.5 Hz, H-6"), 4.42-4.45 (m, 1H, H-4'), 4.43 (q, 2H, J 7.1 Hz, $\mathrm{CH}_{2}-\mathrm{CH}_{3}$ ), 4.64 (dd, 1H, J 8.0, 2.5 Hz, H-3'), 4.75 (dd, 1H, J 14.0, $2.5 \mathrm{~Hz}, \mathrm{H}-6$ ') 5.41 (d, 1H, J 5.0 Hz, H-1'), 7.64 (td, 1H, $J$ 6.0, $2.0 \mathrm{~Hz}, \mathrm{H}-7$ ), 7.67 (td, 1H, J 6.0, 2.0 Hz, H-6), 8.05 (dd, 1H, J 6.0, 2.0 Hz, H-5), 8.12 (dd, 1H, J 6.0, $2.0 \mathrm{~Hz}$, $\mathrm{H}-8) ;{ }^{13} \mathrm{C}$ NMR APT $\left(125.0 \mathrm{MHz}, \mathrm{CDCl}_{3}\right) \delta 11.1\left(\mathrm{C}_{2}-\mathrm{CH}_{3}\right)$, $14.1\left(\mathrm{CH}_{2}-\underline{\mathrm{CH}}_{3}\right), 24.4\left(\underline{\mathrm{CH}}_{3}\right), 24.8\left(\underline{\mathrm{CH}}_{3}\right), 25.4\left(\underline{\mathrm{CH}}_{3}\right), 26.0$ $\left(\mathrm{C}_{3}\right), 46.3\left(\mathrm{C}-6{ }^{\prime}\right), 60.9\left(\mathrm{CH}_{2}-\mathrm{CH}_{3}\right), 67.6\left(\mathrm{C}-5^{\prime}\right), 70.3\left(\mathrm{C}-2^{\prime}\right)$, 70.9 (C-3'), 71.5 (C-4'), 96.2 (C-1'), 108.6 (-OCOO-), 109.5 (-OCOO), 113.7 (C-3), 125.8 (C-5), 126.2 (C-3a), 126.7 (C-8), 129.8 (C-9a), 132.7 (C-6), 132.9 (C-4a), 133.1 (C-7), 133.8 (C-8a), 144.0 (C-2), $164.5\left(\underline{\mathrm{C}}=\mathrm{OOCH}_{2}-\mathrm{CH}_{3}\right), 176.0(\mathrm{C}-4)$, 179.3 (C-9); anal. calcd. for $\mathrm{C}_{28} \mathrm{H}_{31} \mathrm{NO}_{9}$ : C 63.99, H 5.95, N 2.67\%, found: C 63.94, H 6.62, N 2.43\%.

2-Methyl-2-[(5'-deoxy-1',2'-O-isopropylidene-D-xilofuranos5'-yl)]-4,9-dioxo-4,9-dihydro-1 $H$-benzo[f]indole-3-ethyl carboxylate (6c)

The compound $\mathbf{6 c}$ was obtained as a yellow solid, mp 161-163 ${ }^{\circ} \mathrm{C}$, with $43 \%$ yield. IR (film) $\mathrm{v} / \mathrm{cm}^{-1} 1608$ and $1679(\mathrm{C}=\mathrm{O}), 1566(\mathrm{C}=\mathrm{C}) ;{ }^{1} \mathrm{H}$ NMR $(500.00 \mathrm{MHz}$, $\left.\mathrm{CDCl}_{3}\right) \delta 1.18\left(\mathrm{~s}, 3 \mathrm{H}, \mathrm{C}_{3}\right), 1.29\left(\mathrm{~s}, 3 \mathrm{H}, \mathrm{C}_{3}\right), 1.32(\mathrm{t}, 3 \mathrm{H}$, $\left.J 7.1 \mathrm{~Hz}, \mathrm{CH}_{2}-\mathrm{C}_{3}\right), 2.45$ (s, $\left.3 \mathrm{H}, \mathrm{C}_{2}-\mathrm{C}_{3}\right), 4.18-4.22(\mathrm{~m}$, 1H, H-5"), 4.22-4.26 (m, 2H, H-3'and H4'), 4.34 (q, 2H, J $7.1 \mathrm{~Hz}, \underline{\mathrm{C}}_{2}-\mathrm{CH}_{3}$ ), 4.48 (d, 1H, J $3.5 \mathrm{~Hz}, \mathrm{H}-2$ '), 5.03 (dd, 1H, J 14.0, 4.0 Hz, H-5'), 5.86 (d, 1H, J3.5 Hz, H-1'), 7.55-7.57 (m, 2H, H-6 and H-7), $8.00(\mathrm{dd}, 1 \mathrm{H}, J 6.0,2.0 \mathrm{~Hz}$, $\mathrm{H}-5), 8.09$ (dd, 1H, $J$ 6.0, $2.0 \mathrm{~Hz}, \mathrm{H}-8$ ); ${ }^{13} \mathrm{C}$ NMR APT $\left(125.0 \mathrm{MHz}, \mathrm{CDCl}_{3}\right) \delta 11.3\left(\mathrm{C}_{2}-\underline{\mathrm{CH}}_{3}\right), 14.3\left(\mathrm{CH}_{2}-\underline{\mathrm{CH}}_{3}\right)$, $26.3\left(\underline{\mathrm{CH}}_{3}\right), 26.9\left(\underline{\mathrm{CH}}_{3}\right), 44.3\left(\mathrm{C}-5^{\prime}\right), 61.4\left(\underline{\mathrm{CH}}_{2}-\mathrm{CH}_{3}\right)$, 74.9 (C-4'), 80.7 (C-3'), 85.4 (C-2'), 104.8 (C-1'), 112.1 (-OCO-), 115.0 (C-3), 126.5 (C-5), 126.6 (C-3a), 127.0 (C-8), 129.9 (C-9a), 133.2 (C-6), 133.2 (C-4a), 133.7 (C-7), 133.9 (C-8a), $143.4(\mathrm{C}-2), 164.7\left(\mathrm{C}=\mathrm{OOCH}_{2}-\mathrm{CH}_{3}\right), 176.9$ (C-4), 179.4 (C-9); anal. calcd. for $\mathrm{C}_{24} \mathrm{H}_{25} \mathrm{NO}_{8}$ : C 63.29, H 5.53, N 3.08\%, found: C 62.46, H 5.70, N 3.28\%.

3-Acetyl-2-methyl-1-(methyl-5'-deoxy-2', 3'-O-isopropylidene- $\beta$-D-methylfuranosid-5'-yl)-4,9-dioxo4,9-dihydro-1 $\mathrm{H}$-benzo[f]indole (7a)

The compound $7 \mathbf{a}$ was obtained as a yellow solid, mp 210-212 ${ }^{\circ} \mathrm{C}$, with $54 \%$ yield. IR ( $\mathrm{KBr}$ pellets) $\mathrm{v} / \mathrm{cm}^{-1}$ 1683 and $1601(\mathrm{C}=\mathrm{O}), 1567(\mathrm{C}=\mathrm{C}) ;{ }^{1} \mathrm{H}$ NMR $(500.00 \mathrm{MHz}$, $\left.\mathrm{CDCl}_{3}\right) \delta 1.27\left(\mathrm{~s}, 3 \mathrm{H}, \mathrm{C}_{3}\right), 1.43\left(\mathrm{~s}, 3 \mathrm{H}, \mathrm{CH}_{3}\right), 2.48(\mathrm{~s}$, $\left.3 \mathrm{H}, \mathrm{C}_{2}-\mathrm{C}_{3}\right), 2.70\left(\mathrm{~s}, 3 \mathrm{H}, \mathrm{C}=\mathrm{OC}_{3}\right), 3.45\left(\mathrm{~s}, 3 \mathrm{H}, \mathrm{OC}_{3}\right)$, 4.30 (dd, 1H, $J 15.0,5.0 \mathrm{~Hz}, \mathrm{H}-5$ "), 4.50 (dd, $1 \mathrm{H}, J$ 10.0, $\left.5.0 \mathrm{~Hz}, \mathrm{H}-4^{\prime}\right), 4.74$ (d, 1H, J 5.0 Hz, H-3'), 4.78 (d, 1H, J 5.0 Hz, H-2'), 5.02-5.06 (m, 1H, H-5'), 5.03 (s, 1H, H-1'), 7.68-7.72 (m, 2H, H-6, H-7), 8.13 (d, 1H, J 9.0 Hz, H-5), $8.16(\mathrm{~d}, 1 \mathrm{H}, J 9.0 \mathrm{~Hz}, \mathrm{H}-8) ;{ }^{13} \mathrm{C}$ NMR APT $(125.0 \mathrm{MHz}$, $\left.\mathrm{CDCl}_{3}\right) \delta 11.3\left(\mathrm{C}_{2}-\underline{\mathrm{CH}}_{3}\right), 25.2\left(\underline{\mathrm{CH}}_{3}\right), 26.6\left(\underline{\mathrm{CH}}_{3}\right), 31.8$ $\left(\mathrm{C}=\mathrm{OCH}_{3}\right), 48.3\left(\mathrm{C}-5\right.$ '), $55.9\left(\mathrm{OCH}_{3}\right), 81.9(\mathrm{C}-3$ '), 85.4 (C-2'), 85.8 (C-4'), 110.7 (C-1'), 113.0 (-Oㅡㅇ-), 123.3 (C-3), 125.7 (C-3a), 126.6 (C-5), 126.8 (C-8), 129.7 (C-9a), 133.3 (C-6), 133.4 (C-4a), 133.5 (C-7), 141.8 (C-2), 176.3 (C-4), 180.7 (C-9), $199.2\left(\underline{\mathrm{C}}=\mathrm{OCH}_{3}\right)$; anal. calcd. for $\mathrm{C}_{24} \mathrm{H}_{25} \mathrm{NO}_{7}$ : C 65.59, H 5.73, N 3.19\%, found: C 65.10, H 6.05, N 3.27\%.

3-Acetyl-2-methyl-4-[(6'-deoxy-1',2': 3', 4'-di-O-isopropylidene-D-galactopiranos-6'-yl)methyl]-4,9-dioxo4,9-dihydro-1 $\mathrm{H}$-benzo[f]indole (7b)

The compound $\mathbf{7 b}$ was obtained as a yellow solid, mp 197-198 ${ }^{\circ} \mathrm{C}$, with $44 \%$ yield. IR (film) $\mathrm{v} / \mathrm{cm}^{-1} 1609$ and $1678(\mathrm{C}=\mathrm{O}), 1572(\mathrm{C}=\mathrm{C}) ;{ }^{1} \mathrm{H}$ NMR $(500.00 \mathrm{MHz}$, $\left.\mathrm{CDCl}_{3}\right) \delta 1.17$ (s, $\left.3 \mathrm{H}, \mathrm{C}_{3}\right), 1.19\left(\mathrm{~s}, 3 \mathrm{H}, \mathrm{C}_{3}\right), 1.37(\mathrm{~s}$, $\left.3 \mathrm{H}, \underline{\mathrm{C}}_{3}\right), 1.50$ (s, $\left.3 \mathrm{H}, \mathrm{C}_{3}\right), 2.43$ (s, 3H, $\left.\mathrm{C}_{2}-\mathrm{C}_{3}\right), 2.70$ (s, $\left.3 \mathrm{H}, \mathrm{C}=\mathrm{OC}_{3}\right), 4.23-4.24(\mathrm{~m}, 1 \mathrm{H}, \mathrm{H}-5$ '), 4.26-4.27 (m, $1 \mathrm{H}$, H-2'), 4.32-4.37 (m, 1H, H-6"), 4.44 (dd, 1H, J 8.0, 1.0 Hz, H-4'), 4.65 (dd, 1H, J 8.0, 2.5 Hz, H-3'), 4.74 (dd, $1 \mathrm{H}$, $J$ 14.0, 2.5 Hz, H-6'), 5.41 (d, 1H, J 5.0 Hz, H-1'), 7.65-7.67 (m, 2H, H-6, H-7), 8.08 (d, 1H, J 9.0 Hz, H-5), 8.12 (d, 1H, $J 9.0 \mathrm{~Hz}, \mathrm{H}-8) ;{ }^{13} \mathrm{C}$ NMR APT (125.0 MHz, $\left.\mathrm{CDCl}_{3}\right) \delta 11.4$ $\left(\mathrm{C}_{2}-\underline{\mathrm{CH}}_{3}\right), 24.7\left(\underline{\mathrm{CH}}_{3}\right), 25.0\left(\underline{\mathrm{CH}}_{3}\right), 25.6\left(\underline{\mathrm{CH}_{3}}\right), 26.3\left(\underline{\mathrm{CH}}_{3}\right)$, $31.9\left(\mathrm{C}=\mathrm{OCH}_{3}\right), 46.4\left(\mathrm{C}-6^{\prime}\right), 67.7\left(\mathrm{C}-5^{\prime}\right), 70.5\left(\mathrm{C}-2^{\prime}\right), 71.2$ (C-3'), 71.7 (C-4'), 96.5 (C-1'), 108.8 (-OCOO-), 109.8 (-OCO-), 122.7 (C-3), 125.8 (C-3a), 126.2 (C-5), 126.9 (C-8), 129.7 (C-9a), 133.3 (C-6), 133.4 (C-4a and C-8a), 133.8 (C-7), 143.9 (C-2), 176.2 (C-4), 180.9 (C-9), 199.4 $\left(\underline{\mathrm{C}}=\mathrm{OCH}_{3}\right)$; anal. calcd. for $\mathrm{C}_{27} \mathrm{H}_{29} \mathrm{NO}_{8}$ : C 65.44, H 5.90, N 2.83\%, found: C 66.20, H 6.47, N $2.59 \%$.

3-Methyl-2-methyl-2-[(5'-deoxy-1',2'-O-isopropylideneD-xilofuranos-5'-yl)]-4,9-dioxo-4,9-dihydro- $1 H$-benzo[f] indole (7c)

The compound $\mathbf{7 c}$ was obtained as a yellow solid, $\mathrm{mp}$ $227-228{ }^{\circ} \mathrm{C}$, with $48 \%$ yield. IR (film) $\mathrm{v} / \mathrm{cm}^{-1} 1608$ and $1679(\mathrm{C}=\mathrm{O}), 1566(\mathrm{C}=\mathrm{C}) ;{ }^{1} \mathrm{H}$ NMR $\left(500.00 \mathrm{MHz}, \mathrm{CDCl}_{3}\right)$ $\delta 1.28\left(\mathrm{~s}, 3 \mathrm{H}, \mathrm{C}_{3}\right), 1.40$ (s, 3H, $\left.\underline{\mathrm{H}}_{3}\right), 2.49$ (s, 3H, $\left.\mathrm{C}_{2}-\mathrm{C}_{3}\right)$, 2.71 (s, 3H, C=OC $\left.\underline{H}_{3}\right), 4.35$ (dd, $1 \mathrm{H}, J 15.0,10.0 \mathrm{~Hz}, \mathrm{H}-5$ "), 4.38-4.39 (m, 1H, H-3'), 4.40 (dd, 1H, J 10.0, $5.0 \mathrm{~Hz}$, H-4'), 4.58 (d, 1H, J 5.0 Hz, H-2'), 5.09 (dd, 1H, J 15.0, 
$5.0 \mathrm{~Hz}, \mathrm{H}-5$ '), 5.96 (d, 1H, J 5.0 Hz, H-1'), 7.67-7.69 (m, $2 \mathrm{H}, \mathrm{H}-6, \mathrm{H}-7$ ), 8.09-8.11 (m, 1H, H-5), 8.12-8.13 (m, $1 \mathrm{H}, \mathrm{H}-8) ;{ }^{13} \mathrm{C}$ NMR APT $\left(125.0 \mathrm{MHz}, \mathrm{CDCl}_{3}\right) \delta 11.0$ $\left(\mathrm{C}_{2}-\underline{\mathrm{CH}}_{3}\right), 25.9\left(\underline{\mathrm{CH}}_{3}\right), 26.6\left(\underline{\mathrm{CH}}_{3}\right), 31.5\left(\mathrm{C}=\mathrm{OC}_{3}\right), 44.7$ (C-5'), 74.8 (C-4'), 80.3 (C-3'), 85.2 (C-2'), 104.6 (C-1'), 111.8 (-OCO-), 123.2 (C-3), 125.7 (C-3a), 126.3 (C-5), 126.7 (C-8), 129.3 (C-9a), 133.0 (C-6), 133.2 (C-4a), 133.4 (C-8a), 133.5 (C-7), 142.9 (C-2), 176.5 (C-4), 180.4 (C-9), $199.3\left(\underline{\mathrm{C}}=\mathrm{OCH}_{3}\right)$; anal. calcd. for $\mathrm{C}_{25} \mathrm{H}_{27} \mathrm{NO}_{8}$ : C 64.93, H 5.45, N 3.29\%, found: C 65.64, H 6.38, N 3.01\%.

Synthesis of 2-chloro-3-( $\alpha$-cyano- $\alpha$-ethoxycarbonyl-methyl)1,4-naphthoquinone (22)

To a $125 \mathrm{~mL}$ round bottom flask were added $1.0 \mathrm{mmol}$ of ethyl cianoacetate (21), $2 \mathrm{mmol}$ of $\mathrm{K}_{2} \mathrm{CO}_{3}$ and $100 \mathrm{~mL}$ of acetonitrile. The reaction was kept under stirring at room temperature for $10 \mathrm{~min}$. Then $1.0 \mathrm{mmol}$ of 2,3-dichloronaphthoquinone (20) was added and stirred for $20 \mathrm{~min}$. The product $\mathbf{2 2}$ was purified by chromatography on a silica gel column using hexane/ethyl acetate (7:3) as eluent. This derivative was obtained as a brown solid in $73 \%$ yield.

\section{Synthesis of benzo[f]indole-4,9-diones $5 \mathbf{a}-5 \mathbf{c}$}

To a $50 \mathrm{~mL}$ round bottom flask containing compound 22 $(1.65 \mathrm{mmol})$ dissolved in $50 \mathrm{~mL}$ of ethanol were added $3.3 \mathrm{mmol}$ of aminocarbohydrates $\mathbf{9 a - 9 c}$. The reaction was kept under reflux for $20 \mathrm{~h}$. The annelated product was purified by chromatography on a silica gel column, using a gradient elution of $90-80 \%(\mathrm{v} / \mathrm{v})$ hexane in ethyl acetate.

2-Amino-2-methyl-1-(methyl-5'-deoxy-2', 3'-O-isopropylidene- $\beta$-D-methylfuranosid-5'-yl)-4,9-dioxo4,9-dihydro- $1 H$-benzo[f]indole-3-ethyl carboxylate (5a)

The compound $\mathbf{5 a}$ was obtained as a red solid, $\mathrm{mp} 154-155{ }^{\circ} \mathrm{C}$, with $48 \%$ yield. IR ( $\mathrm{KBr}$ pellets) $\mathrm{v} / \mathrm{cm}^{-1} 1683$ and $1601(\mathrm{C}=\mathrm{O}), 1567(\mathrm{C}=\mathrm{C}) ;{ }^{1} \mathrm{H}$ NMR $\left(500.00 \mathrm{MHz}, \mathrm{CDCl}_{3}\right) \delta 1.35\left(\mathrm{~s}, 3 \mathrm{H}, \mathrm{C}_{3}\right), 1.46(\mathrm{t}, 3 \mathrm{H}$, J $\left.7.0 \mathrm{~Hz}, \mathrm{CH}_{2}-\mathrm{C}_{3}\right), 1.47$ (s, $\left.3 \mathrm{H}, \mathrm{C}_{3}\right), 3.49$ (s, $3 \mathrm{H}$, $\left.\mathrm{OC}_{3}\right), 3.98$ (dd, $1 \mathrm{H}, J 14.5,9.5 \mathrm{~Hz}, \mathrm{H}-5$ "), 4.40 (q, $\left.2 \mathrm{H}, J 7.0 \mathrm{~Hz}, \mathrm{C}_{2}-\mathrm{CH}_{3}\right), 4.70$ (d, 1H, J $3.5 \mathrm{~Hz}, \mathrm{H}-4^{\prime}$ ), 4.73 (d, 1H, J 6.0 Hz, H-2'), 4.82 (dd, 1H, J 6.0, $1.0 \mathrm{~Hz}$, H-3'), 4.99 (dd, 1H, J 14.5, 3.5 Hz, H-5'), 5.03 (s, 1H, H-1'), 6.45 (s, 1H, $\underline{\mathrm{H}}_{2}$ ), 7.60-7.62 (m, 2H, H-6, H-7), 8.05-8.06 (m, 1H, H-5), 8.09-8.11 (m, 1H, H-8); ${ }^{13} \mathrm{C} \mathrm{NMR}$ APT $\left(125.0 \mathrm{MHz}, \mathrm{CDCl}_{3}\right) \delta 14.6\left(\mathrm{CH}_{2}-\underline{\mathrm{CH}}_{3}\right), 25.2\left(\underline{\mathrm{CH}}_{3}\right)$, $26.6\left(\underline{\mathrm{CH}}_{3}\right), 48.3(\mathrm{C}-5), 56.0\left(\mathrm{O}^{\prime} \mathrm{H}_{3}\right), 60.6\left(\underline{\mathrm{CH}}_{2}-\mathrm{CH}_{3}\right)$, 82.0 (C-3'), 84.3 (C-2'), 87.2 (C-4'), 94.0 (C-1'), 111.5 (-OCOO-), 113.4 (C-3), 125.6 (C-5), 126.2 (C-3a, C-9a),
126.8 (C-8), 132.8 (C-6), 132.8 (C-7), 133.0 (C-4a), 134.0 (C-8a), $153.0(\mathrm{C}-2), 165.8\left(\underline{\mathrm{C}}=\mathrm{OOCH}_{2}-\mathrm{CH}_{3}\right), 175.3(\mathrm{C}-4)$, $179.6(\mathrm{C}-9)$.

2-Amino-2-methyl-4-[(6'-deoxy-1', 2': 3', 4'-di-O-isopropylidene-D-galactopiranos-6'-yl)methyl]-4,9-dioxo4,9-dihydro-1 $H$-benzo[f]indole-3-ethyl carboxylate (5b)

The compound $\mathbf{5 b}$ was obtained as a red solid, mp $178-180{ }^{\circ} \mathrm{C}$, with $41 \%$ yield. IR (film) $v / \mathrm{cm}^{-1} 1609$ and $1678(\mathrm{C}=\mathrm{O}), 1572(\mathrm{C}=\mathrm{C}) ;{ }^{1} \mathrm{H} \mathrm{NMR}\left(500.00 \mathrm{MHz}, \mathrm{CDCl}_{3}\right)$ $\delta 1.18\left(\mathrm{~s}, 3 \mathrm{H}, \mathrm{C}_{3}\right), 1.24$ (s, 3H, $\left.\underline{\mathrm{CH}}_{3}\right), 1.30$ (s, 3H, $\left.\underline{\mathrm{CH}}_{3}\right)$, 1.38 (t, $\left.3 \mathrm{H}, J 7.0 \mathrm{~Hz}, \mathrm{CH}_{2}-\mathrm{C}_{3}\right), 1.44$ (s, $\left.3 \mathrm{H}, \underline{\mathrm{C}}_{3}\right), 4.14$ (dd, 1H, J 14.5, 8.0 Hz, H-6"), 4.22-4.23 (m, 1H, H-5'), 4.24 (dd, 1H, J 4.5, $2.5 \mathrm{~Hz}, \mathrm{H}-2^{\prime}$ ) , 4.32 (q, 2H, J 7.0 Hz, $\left.\mathrm{C}_{2}-\mathrm{CH}_{3}\right), 4.37$ (dd, $\left.1 \mathrm{H}, J 8.0,2.0 \mathrm{~Hz}, \mathrm{H}-4^{\prime}\right), 4.59$ (dd, $1 \mathrm{H}$, $J$ 8.0, 2.0 Hz, H-3'), 4.70 (dd, 1H, J 14.5, 3.5 Hz, H-6'), 5.44 (d, 1H, J 5.0 Hz, H-1'), 6.06 (s, 2H, $\left.\underline{\mathrm{H}}_{2}\right), 7.51-7.55$ (m, 2H, H-6, H-7), 7.94 (dd, 1H, J 5.5, 2.5 Hz, H-5), 8.01 (dd, $1 \mathrm{H}, J 5.5,2.5 \mathrm{~Hz}, \mathrm{H}-8) ;{ }^{13} \mathrm{C}$ NMR APT $(125.0 \mathrm{MHz}$, $\left.\mathrm{CDCl}_{3}\right) \delta 14.6\left(\mathrm{CH}_{2}-\underline{\mathrm{CH}}_{3}\right), 24.4\left(\underline{\mathrm{CH}}_{3}\right), 25.1\left(\underline{\mathrm{C}}_{3}\right), 26.0$ $\left(\underline{\mathrm{CH}}_{3}\right), 26.2\left(\underline{\mathrm{CH}}_{3}\right), 45.9(\mathrm{C}-6), 60.6\left(\mathrm{CH}_{2}-\mathrm{CH}_{3}\right), 68.6$ (C-5'), 70.7 (C-2'), 70.9 (C-3'), 71.5 (C-4'), 94.5 (C-3), 96.3 (C-1'), 109.3 (-OCOO-), 109.8 (-OCO-), 125.4 (C-5), 126.6 (C-3a), 126.8 (C-8), 126.8 (C-9a), 132.7 (C-6), 132.8 (C-7), 132.9 (C-4a), 134.1 (C-8a), 153.5 (C-2), 165.6 $\left(\underline{\mathrm{C}}=\mathrm{OOCH}_{2}-\mathrm{CH}_{3}\right), 175.3$ (C-4), 179.6 (C-9); anal. calcd. for $\mathrm{C}_{27} \mathrm{H}_{30} \mathrm{~N}_{2} \mathrm{O}_{9}$ : C 61.59, H 5.74, N 5.32\%, found: C 61.54, H 6.00, N 5.05\%.

2-Amino-2-methyl-2-[(5'-deoxy-1',2'-O-isopropylideneD-xilofuranos-5'-yl)]-4,9-dioxo-4,9-dihydro-1H-benzo[f] indole-3-ethyl carboxylate (5c)

The compound $\mathbf{5 c}$ was obtained as a red solid, mp 163$166{ }^{\circ} \mathrm{C}$, with $56 \%$ yield. IR (film) $v / \mathrm{cm}^{-1} 1608$ and 1679 $(\mathrm{C}=\mathrm{O}), 1566(\mathrm{C}=\mathrm{C}) ;{ }^{1} \mathrm{H}$ NMR $\left(500.00 \mathrm{MHz}, \mathrm{CDCl}_{3}\right) \delta 1.29$ (s, $\left.3 \mathrm{H}, \mathrm{C}_{3}\right), 1.42\left(\mathrm{~s}, 3 \mathrm{H}, \mathrm{C}_{3}\right), 1.44(\mathrm{t}, 3 \mathrm{H}, J 7.0 \mathrm{~Hz}$, $\left.\mathrm{CH}_{2}-\mathrm{CH}_{3}\right), 4.22-4.26$ (m, 1H, H-5"), 4.39 (q, $2 \mathrm{H}, J 7.0 \mathrm{~Hz}$, $\left.\mathrm{C}_{2}-\mathrm{CH}_{3}\right), 4.45(\mathrm{~d}, 1 \mathrm{H}, J 3.0 \mathrm{~Hz}, \mathrm{H}-4$ ') $4.52(\mathrm{~d}, 1 \mathrm{H}$, $J 3.0 \mathrm{~Hz}, \mathrm{H}-3^{\prime}$ ), 4.59 (d, 1H, J 3.5 Hz, H-2'), 5.10 (dd, 1H, $J$ 15.0, 3.0 Hz, H-5'), 6.02 (d, 1H, J 3.5 Hz, H-1'), 7.60-7.62 (m, 2H, H-6, H-7), 8.00 (dd, 1H, J 5.5, 2.5 Hz, H-5), 8.09 (dd, $1 \mathrm{H}, J$ 5.5, $2.5 \mathrm{~Hz}, \mathrm{H}-8) ;{ }^{13} \mathrm{C}$ NMR APT (125.0 MHz, $\left.\mathrm{CDCl}_{3}\right) \delta 14.6\left(\mathrm{CH}_{2}-\underline{\mathrm{CH}}_{3}\right), 26.3\left(\underline{\mathrm{CH}}_{3}\right), 26.9\left(\underline{\mathrm{CH}}_{3}\right), 44.6$ (C-5'), $60.7\left(\mathrm{CH}_{2}-\mathrm{CH}_{3}\right), 75.4$ (C-4'), 81.0 (C-3'), 85.6 (C-2'), 94.8 (C-3), 105.0 (C-1'), 112.4 (-OCO-), 125.5 (C-5), 126.6 (C-3a), 126.9 (C-8), 127.0 (C-9a), 132.8 (C-6), 132.9 (C-4a), 133.0 (C-7), 133.9 (C-8a), 153.4 (C-2), 165.5 $\left(\underline{\mathrm{C}}=\mathrm{OOCH}_{2}-\mathrm{CH}_{3}\right), 175.7$ (C-4), 179.5 (C-9); anal. calcd. for $\mathrm{C}_{23} \mathrm{H}_{24} \mathrm{~N}_{2} \mathrm{O}_{8}$ : C 60.52, H 5.30, N 6.14\%, found: C 59.51, H 5.60, N 5.88\%. 


\section{Supplementary Information}

Supplementary data are available free of charge at http://jbcs.sbq.org.br as PDF file.

\section{Acknowledgments}

We acknowledge CNPq/Universal (420491/2016-3), FIOCRUZ, CAPES (post-doctoral fellowship for F. S. G.), FAPERJ (CNE, E-26/202.955/2016; E-26/202.763/2018 and E-26/010.001837/2015 for P. D. F.) and CNPQ (405332/2016 and 304394/2017-3 for P. D. F.) for financial support and research fellowships.

\section{Author Contributions}

Flaviana R. F. Dias was responsible for the investigation of the synthesis and writing original draft; Fabiana S. Guerra for the investigation of the biological activity and writing original draft; Fernanda A. Lima for the investigation of the synthesis; Yasmin K. C. de Castro for the investigation of the synthesis; Vitor F. Ferreira for the writing review and editing of the synthesis; Vinícius R. Campos for the supervision and writing review and editing of the synthesis; Patrícia D. Fernandes for the project administration, writing original draft and writing review and editing of the biological activity; Anna C. Cunha for the project administration, writing original draft and writing review and editing of the synthesis.

\section{References}

1. Wani, T. H.; Surendran, S.; Jana, A.; Chakrabarty, A.; Chowdhury, G.; Chem. Res. Toxicol. 2018, 31, 612.

2. Ferreira, S. B.; Gonzaga, D. T. G.; Santos, W. C.; Araújo, K. G. L.; Ferreira, V. F.; Rev. Virtual Quim. 2010, 2, 140.

3. da Silva, M. N.; Ferreira, V. F.; de Souza, M. C. B. V.; Quim. Nova 2003, 26, 407.

4. Romão, L.; do Canto, V. P.; Netz, P. A.; Moura-Neto, V.; Pinto, A. C.; Follmer, C.; Anti-Cancer Drugs 2018, 29, 520.

5. Adhikari, A.; Mahar, K. S.; Int. J. Pharm. Pharm. Sci. 2016, 8 , 17.

6. Luo, D.; Carter, K. A.; Miranda, D.; Lovell, J. F.; Adv. Sci. 2017, 4, 1600106.

7. Choi, J. S.; Berdis, A.; Eur. J. Haematol. 2020, 4, 97.

8. Temperini, C.; Cirilli, M.; Aschic, M.; Ughetto, G.; Bioorg. Med. Chem. 2005, 13, 1673.

9. da Silva, W. A.; da Silva, L. C. R. P.; Campos, V. R.; de Souza, M. C. B. V.; Ferreira, V. F.; dos Santos, A. C. P. B.; Sathler, P. C.; de Almeida, G. S.; Dias, F. R. F.; Cabral, L. M.; de Azeredo, R. B. V.; Cunha, A. C.; Future Med. Chem. 2018, 10, 527.
10. Ramalingam, B. M.; Moorthy, N. D.; Chowdhury, S. R.; Mageshwaran, T.; Vellaichamy, E.; Saha, S.; Ganesan, K.; Rajesh, B. N.; Igbal, S.; Majemder, H. K.; Gunasekaran, K.; Siva, R.; Mohanakrishnan, A. K.; J. Med. Chem. 2018, 61, 1285.

11. Yang, J.; Li, W.; Luo, L.; Jiang, M.; Zhu, C.; Qin, B.; Yin, H.; Yuan, X.; Yin, X.; Zhang, J.; Luo, Z.; Du, Y.; You, J.; Biomaterials 2018, 182, 145.

12. Kelly, R. A.; Leedale, J.; Calleja, D.; Enoch, S. J.; Harrell, A.; Chadwick, A. E.; Webb, S.; Sci. Rep. 2019, 9, 6333.

13. Glorieux, C.; Calderon, P. B.; Antioxidants 2019, 8, 369.

14. Huang, G.; Mei, X.; Curr. Drug Targets 2014, 15, 780.

15. Calvaresi, E. C.; Hergenrother, P. J.; Chem. Sci. 2013, 4, 2319.

16. Campos, V. R.; Santos, E. A.; Ferreira, V. F.; Montenegro, R. C.; de Souza, M. C. B. V.; Costa-Lotufo, L. V.; de Moraes, M. O.; Regufe, A. K. P.; Jordão, A. K.; Pinto, A. C.; Resende, J. A. L. C.; Cunha, A. C.; RSC Adv. 2012, 2, 11438.

17. Campos, V. R.; Silva, W. A.; Ferreira, V. F.; Souza, C. S.; Fernandes, P. D.; Moreira, V. N.; Rocha, D. R.; Dias, F. R. F.; Montenegro, R. C.; de Souza, M. C. B. V.; Boechat, F. C. S.; Franco, C. F. J.; Resende, J. A. L. C.; Cunha, A. C.; RSC Adv. 2015, 5, 96222.

18. Park, H. J.; Lee, H. J.; Lee, E. J.; Hwang, H. J.; Shin, S. H.; Suh, M. E.; Kim, C.; Kim, H. J.; Seo, E. K.; Lee, S. K.; Biosci. Biotechnol. Biochem. 2003, 67, 1944.

19. Lee, E. J.; Lee, H. J.; Park, H. J.; Min, H. Y.; Suh, M. E.; Chung, H. J.; Lee, S. K.; Bioorg. Med. Chem. Lett. 2004, 14, 5175.

20. Park, H. J.; Lee, H. J.; Min, H. Y.; Chung, H. J.; Suh, M. E.; Choo, H. Y. P.; Kim, C.; Kim, H. J.; Seo, E. K.; Lee, S. K.; Eur. J. Pharm. 2005, 527, 31.

21. Lee, H. J.; Suh, M. E.; Lee, C. O.; Bioorg. Med. Chem. 2003, 11,1511 .

22. Nguyen, T. Q.; Nhat, T. G. L.; Ngoc, D. V.; Thi, T. A. D.; Nguyen, H. T.; Thi, P. H.; Nguyen, H. H.; Cao, H. T.; Tehrani, K. A.; Nguyen, T. V.; Tetrahedron Lett. 2016, 57, 4352.

23. Tseng, C.; Wu, Y.; Chuang, C.; Tetrahedron 2002, 58, 7625.

24. Chen, Y.; Tseng, C.; Chen, Y.; Hwang, T.; Tzeng, C.; Int. J. Mol. Sci. 2015, 16, 6532.

25. Hsu, Y.; Chuang, C.; Synthesis 2014, 46, 3374.

26. Tseng, C.; Wu, Y.; Chuang, C.; Tetrahedron 2004, 60, 12249.

27. Wu, Y.; Chuang, C.; Lin, P.; Tetrahedron 2001, 57, 5543.

28. Chuang, C.; Wu, Y.; Jiang, M.; Tetrahedron 1999, 55, 11229.

29. Suh, M.; Park, S.; Lee, S.; Bioorg. Med. Chem. 2001, 9, 2979.

30. Suryavanshi, P. A.; Sridharan, V.; Menéndez, J. C.; Org. Biomol. Chem. 2010, 8, 3426.

31. Hu, H.; Liu, Y.; Ye, M.; Xu, J.; Synlett 2006, 12, 1913.

32. Sun, J.; Wang, X.; Liu, Y.; J. Org. Chem. 2013, 78, 10560.

33. Yamashita, M.; Ueda, K.; Sakaguchi, K.; Iida, A.; Tetrahedron Lett. 2011, 52, 4665.

34. Shvartsberg, M. S.; Kolodina, E. A.; Lebedeva, N. I.; Fedenok, L. G.; Tetrahedron Lett. 2009, 50, 6769. 
35. Zhang, L.; Zhang, X.; Lu, Z.; Zhang, D.; Xu, X.; Tetrahedron 2016, 72, 7926.

36. Weeratunga, G.; Prasad, G. K. B.; Dilley, J.; Taylor, N. J.; Dmitrienko, G. I.; Tetrahedron Lett. 1990, 31, 5713.

37. Guo, S.; Chen, B.; Guo, X.; Zhang, G.; Yu, Y.; Tetrahedron 2015, 71, 9371.

38. Baiju, T. V.; Almeida, R. G.; Sivanandan, S. T.; de Simone, C. A.; Brito, L. M.; Cavalcanti, B. C.; Pessoa, C.; Namboothiri, I. N. N.; da Silva Jr., E. N.; Eur. J. Med. Chem. 2018, 151, 686.

39. Privitera, M. D.; Ann. Pharmacother. 1997, 31, 1164.

40. Dias, F. R. F.; Novais, J. S.; Devillart, T. A. N. S.; da Silva, W. A.; Ferreira, M. O.; Loureiro, R. S.; Campos, V. R.; Ferreira, V. F.; de Souza, M. C. B. V.; Castro, H. C.; Cunha, A. C.; Eur. J. Med. Chem. 2018, 156, 1.

41. Franco, C. F. J.; Jordão, A. K.; Ferreira, V. F.; Pinto, A. C.; de Souza, M. C. B. V.; Resende, J. A. L. C.; Cunha, A. C.; J. Braz. Chem. Soc. 2011, 22, 187.

42. Novais, J. S.; Campos, V. R.; Silva, A. C. J. A.; Souza, M. C. B. V.; Ferreira, V. F.; Keller, V. G. L.; Ferreira, M. O.; Dias, F. R. F.; Vitorino, M. I.; Sathler, P. C.; Santana, M. V.; Resende, J. A. L. C.; Castro, H. C.; Cunha, A. C.; RSC Adv. 2017, 7, 18311.
43. Karakas, D.; Ari, F.; Ulukaya, E.; Turk. J. Biol. 2017, 41, 919. 44. Dent, R.; Trudeau, M.; Pritchard, K. I.; Hanna, W. M.; Kahn, H. K.; Sawka, C. A.; Lickley, L. A.; Rawlinson, E.; Sun, P.; Narod, S. A.; Clin. Cancer Res. 2007, 13, 4429.

45. Rakha, E. A.; Chan, S.; Clin. Oncol. (R. Coll. Radiol.) 2011, $23,587$.

46. Han, J.; Lim, W.; You, D.; Jeong, Y.; Kim, S.; Lee, J. E.; Shin, T. H.; Lee, G.; Park, S.; J. Oncol. 2019, 2019, ID 1345026.

47. Moongkarndi, P.; Kosem, N.; Kaslungka, S.; Luanratana, O.; Pongpan, N.; Neungton, N.; J. Ethnopharmacol. 2004, 90, 161.

48. Thorn, C. F.; Oshiro, C.; March, S.; Hernandez-Boussard, T.; McLeod, H.; Klein, T. E.; Altman, R. B.; Pharmacogenomics 2011, 21, 440.

49. Denizot, F.; Lang, R.; J. Immunol. Methods 1986, 89, 271.

50. Malagoli, D.; Invertebr. Survival J. 2007, 4, 92.

51. Schindelin, J.; Arganda-Carreras, I.; Frise, E.; Nat. Methods 2012, 9, 676.

Submitted: June 24, 2020 Published online: October 8, 2020 